\title{
Making and Collecting Instruments in Fair Verona: The Case of the Italian Amateur Scientist Gaetano Spandri (1796-1859)
}

\author{
Roberto Mantovani*
}

Gaetano Spandri (1796-1859) was a "diligent scholar of the physical sciences," a private collector and maker of scientific instruments who worked in Verona in the first half of the nineteenth century. Born in Verona, the city famous as the setting of Shakespeare's iconic masterpiece Romeo and Juliet Spandri was primarily a physicist and astronomer, but he was also interested in meteorology and natural sciences. The main sources of information about his scientific work are handwritten papers, parts of his private correspondence, and scientific reports kept at the Verona Academy of Agriculture. For most of his life, he collaborated with the physicist Giuseppe Zamboni and was in contact with important physicists and astronomers of his time. His private apartment was equipped with a rich library, an astronomical and meteorological observatory, and a large room where he gathered a rich and important collection of scientific instruments.

Key words: Gaetano Spandri; Giuseppe Zamboni; science in Verona; scientific instruments; Academy of Agriculture, Arts and Commerce of Verona; magnetoelectric machine.

\section{An Eclectic Scientist from Verona}

In 1868, Ettore Scipione Righi (1833-94), a scholar and member of the Academy of Agriculture, Arts, and Commerce of Verona, drafted a short description of Gaetano Spandri:

Agronomist, physicist, celebrated naturalist, Spandri was also one of the most respectable members of this Academy, where he read his Memoirs and his Reports on various topics, and where he was a Meteorological Observer. He was a friend of Cavalier Giuseppe Belli, professor of Physics at the University of Pavia, and Abbot Giuseppe Zamboni, also professor of physics at our School. From them, he learned the art of machine building so that the distinguished discoverer of Perpetual Motion [Zamboni] often preferred his machines to

\footnotetext{
* Roberto Mantovani is an Assistant Professor at the University of Urbino Carlo Bo (Italy) and Curator of the Physics Laboratory: Urbino Museum of Science and Technology. His research focuses mainly on the history of scientific instruments.
} 
those made in foreign countries. These machines were available in the Cabinet of the Institute where he was a professor. ${ }^{1}$

Well-off and with no institutional roles, ${ }^{2}$ Spandri (1796-1859) was mainly an expert collector and maker of scientific instruments, a passionate enthusiast of the physical sciences, and particularly keen on electricity, optics, geomagnetism, and electroplating. As it was usual among the scientists of the nineteenth century, he also nurtured several other branches of science, such as astronomy, meteorology, and natural sciences. The primary sources of information about his scientific work are handwritten papers, parts of his private correspondence, and documents related to his commitment as a member of the Academy of Agriculture, Arts, and Commerce of Verona, which he joined in $1838 .{ }^{3}$ In this institution, he presented several memoirs and reports and was appointed meteorological observer. He may have written other scientific texts that we, unfortunately, have no trace of.

For most of his life, he worked in Verona with the physicist Giuseppe Zamboni (1776-1846), with whom he maintained a long-lasting scientific collaboration, strengthened by mutual respect and shared religious faith. He kept a cabinet of physics and an observatory, both stocked with physical and astronomical equipment, in his house. He also enjoyed repairing, maintaining, and making scientific instruments, sometimes delegating the building of the more complex structures to some of his trusted manufacturers.

As an amateur scientist, thanks to a favourable and stimulating scientific environment, he earned the respect of many fellow Italian scientists. He maintained scientific relationships with Francesco Zantedeschi (1797-1873) and Giuseppe Belli (1791-1860) in Pavia, Giambattista Pianciani (1784-1862) in Rome, Cesare Leopoldo Gazzaniga in Desenzano, ${ }^{4}$ and Francesco Carlini (17831862), director of the Brera Observatory, in Milan. These people respected him as a skilled instrument maker and a fine experimenter. According to Zantedeschi, he was a "zealous enthusiast of physical sciences"; to Giovanni Federico Majer, he was a "very diligent scholar of physics"; Pianciani defined him as a "very learned and diligent person in his experiments." ${ }^{6} \mathrm{He}$ was a close and devoted friend of Father Gaspare Bertoni, founder of the Italian Stimmatini religious order, who encouraged him to live a profoundly Christian life.

\section{Short Biographical Notes}

Gaetano Spandri was born in Verona on July 30, 1796, in the heart of the old town on Via Mazzini (Via Nuova at that time), on the corner of Via Quattro Spade, in a building where there is a commemorative plaque today. ${ }^{7}$ His father, a wealthy and pious merchant, raised him with a strict religious upbringing, which would influence him for the rest of his life. In Verona, he attended the Stigmata and St. Sebastian's Catholic schools, distinguishing himself with his strong interest in the scientific subjects. When he was twenty-one, he married Virginia, the young and 
educated daughter of a Veronese aristocrat, Domenico Monga. Virginia gave him a son, Giuseppe (1819-81), who became a poet and philosopher and with whom he had a complex relationship.

Marriage bolstered Spandri's social status: without the need for money, he equipped his home with a fine library, an observatory, and a large room to keep his rich and relevant collection of scientific instruments, which he patiently increased for all his life. Many influential Veronese attended his home, among them the bishop and writer Pietro Aurelio Mutti (1775-1859), the scholar Antonio Cesari (1760-1828), the naturalist Giulio Sandri (1789-1876), and the poet and writer Caterina Bon Brenzoni (1813-56). Spandri helped Bon Brenzoni in her astronomical studies and offered her the use of the observatory and instruments. ${ }^{8}$

Spandri was fond of making sundials, which he preferred to design using mean solar time instead of true solar time, which was predominantly used in the midnineteenth century. In a letter, dated 1840, he hints at the fact that he had spent a "delighted" week drawing a sundial on the wall of an edifice they were building for the Jesuit novices. ${ }^{9}$ Spandri drew a fine sundial on the facade of his house, which is still clearly visible (figure 1). According to one of Spandri's biographers, the sundial was accurately described in a handwritten volume, kept at Spandri's nephew's, which included "self-explanatory drawings and astronomical tables." 10 He died on September 30, 1859. For his works, he was buried as an eminent citizen in the "Ingenio Claris Pantheon" within the Verona Monumental Cemetery. The pantheon is a grave dedicated to prominent people. It counts thirty-two personalities, such as Zamboni and Francesco Zantedeschi, the writer Emilio Salgari, and the publisher Arnoldo Mondadori.

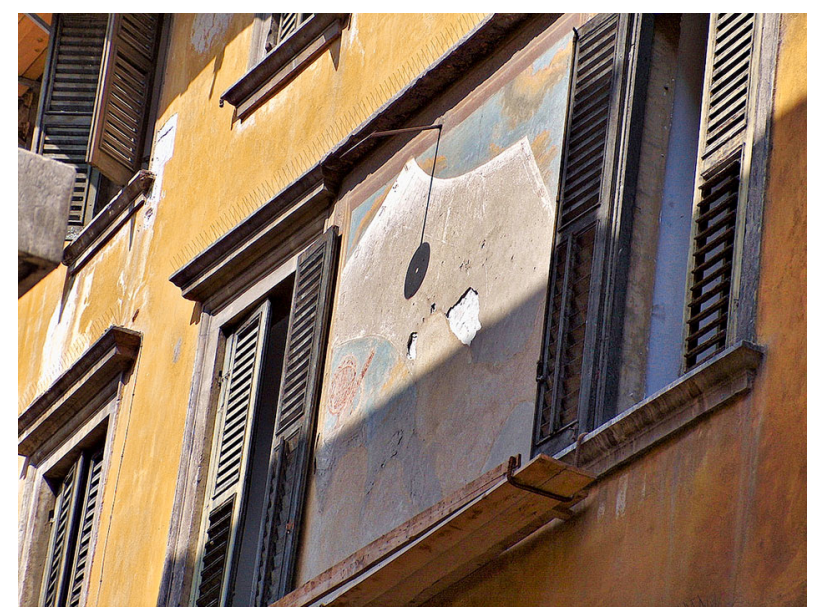

Fig. 1. The sundial designed by Spandri on the wall of his house Credit: Photo by F. Negrini 


\section{The Veronese Scientific Environment}

In the first half of the nineteenth century, Verona became the hub of technicalscientific activity because of the presence of many skilled clockmakers and makers of scientific instruments. They primarily worked alongside Zamboni, a member of the Academy of Agriculture and a teacher of experimental physics at the Imperial High School College of Verona (today, the Scipione Maffei High School in Verona) from its opening in 1805 to 1846 , when he died. With the help of these local craftsmen, Zamboni designed and built several scientific instruments. His name is mainly linked to the invention of the dry pile, a variation of Volta's famous battery. As it did not contain acids or other liquids that could damage the metals, it had the advantage of lasting much longer. With this battery, Zamboni devised two other notable scientific devices. First was the "perpetual electromotive," a spectacular demonstration of an electric pendulum in "perpetual" movement. It was made up of a thin metallic ring pivoted on a light pendular axis. The ring was attracted and repulsed alternately by the poles of a pair of Zamboni dry column piles so that the pendular axis could keep its oscillations continuously for several years (see figure 7). Second was the electric clock, which did not require recharging and exploited the physical principles of the perpetual pendulum. ${ }^{11}$ Today, these important relics, as most of the scientific instruments linked to the Veronese scientist's educational work and research, are kept at the Scipione Maffei High School of Verona. ${ }^{12}$

To make, repair, and improve his devices, Zamboni employed a good number of Veronese clockmakers, instrument makers, and mechanics. The latter gravitated to High School College and the Academy of Agriculture of Verona. Among them were Carlo Streizig, watchmaker and machinist of the cabinet of physics, and the skilled mechanic Jacopo Bertoncelli (1783-1848), physics and chemistry classroom assistant and later teacher of chemistry, botany, and graphic art until $1820 .{ }^{13}$ Zamboni later hired other talented technical assistants from his cabinet to improve the perpetual electromotive and some electric clocks. These included Antonio Pozzi, Domenico Zamboni, and Giovanni Bianchi (1780-1858). A Bianchi's autographed fine electric clock is still kept at the Maffei High School.

Two names are primarily associated with the Academy of Agriculture: Antonio Camerlengo (1768-1836), a watchmaker and fine instrument maker, and Bartolomeo Avesani, the mechanical engineer. Camerlengo presented some of his inventions at the academy, collecting several awards and earning the esteemed title of academic machinist in $1806 .{ }^{14} \mathrm{He}$ devised a large and precise electric clock under Zamboni's supervision, presented in May 1827. The clock (figure 2) consisted of a sophisticated athermic "real pendulum," about one meter long, which, moving isochronously between the ends of the poles of two dry piles, struck the exact second. Avesani, the mechanical engineer, is remembered mainly for his invention of a "simple and inexpensive" new steam engine (figure 3), which was 
awarded a gold medal. For this, he was appointed corresponding member of the Veronese Academy. ${ }^{15}$

Spandri came up in this vibrant scientific environment. According to Abbot Antonio Rivato, teacher of philosophy at the High School in Verona, Spandri and Zamboni's friendship and collaboration began in 1833 and lasted until Zamboni's death. ${ }^{16}$ As an instrument maker and experimenter, Spandri strove to satisfy Zamboni's scientific needs; Zamboni considered Spandri a valuable and diligent assistant. They discussed various topics, and Zamboni would often give Spandri scientific texts and borrow machines to perform demonstrations for his students. ${ }^{17}$ He kept Spandri updated on the scientific news of the day, particularly on new experimental devices. In an undated letter to Spandri, Zamboni wrote: "Here is a nice electroplating sample from our Bertoncelli, but we shall talk about that later. And here is an experiment which I hope will be successful against De la Rive: zinc (lower)-platinum (upper) condenser, platinum capsule containing acidic water,

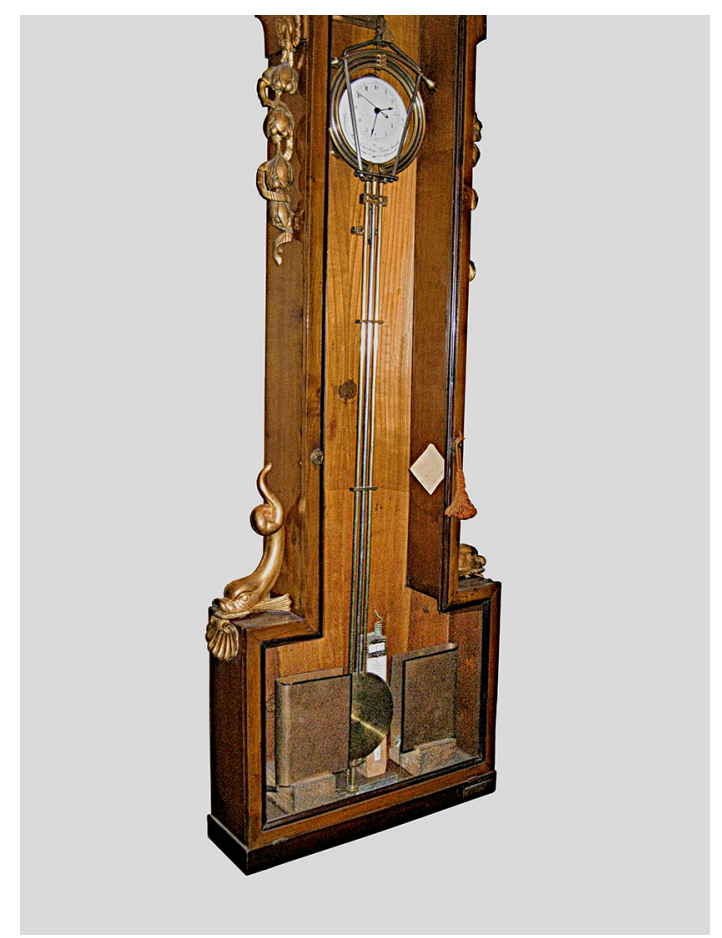

Fig. 2. The "Real Pendulum" designed and built by Camerlengo in 1827, today preserved at the Accademia di Agricoltura, Scienze e Lettere in Verona. Credit: Courtesy of Accademia di Agricoltura, Scienze e Lettere in Verona 


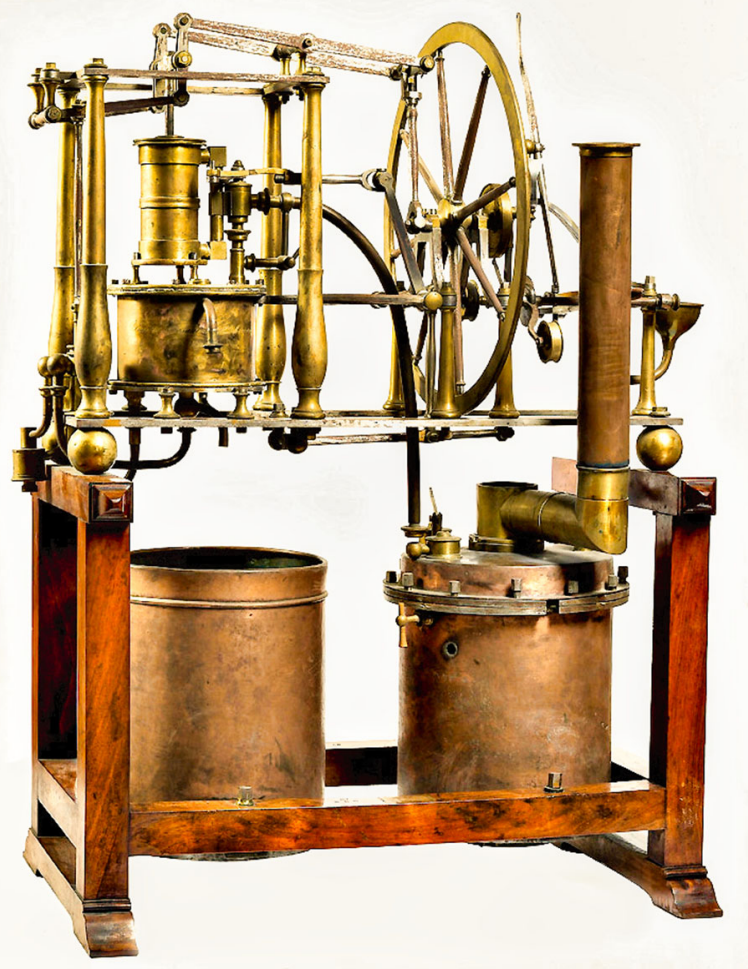

Fig. 3. Steam engine model signed and dated "Bart. ${ }^{\text {eo }}$ Avesani Ing.re Meccanico Verona 1837," today preserved at the high school "Scipione Maffei" in Verona. Credit: Courtesy of Liceo Classico Scipione Maffei in Verona

right-hand thumb must touch the acid, and left hand must hold in its fingers a piece of platinum touching the zinc in the lower condenser. I hope we shall get an excellent positive right there." ${ }^{18}$

Spandri repaired, built, and tested several scientific devices for Zamboni and, on his command, carried out many delicate experiments. In the last years of his life, Zamboni was committed to the design of a new galvanometer, called "dynamical electroscope," which was to improve on Nobili's multiplier and could measure induction currents. ${ }^{19}$ Later, according to Antonio Rivato, who got the information directly from Spandri, once he understood the complexity of the device, he tried to simplify it by perfecting its making and increasing efficiency, but he died before he was able to do it. ${ }^{20}$ 


\section{The Cabinet of Physics}

In a large room of his home in Verona, Spandri assembled a rich collection of scientific devices. They were mainly physical and astronomical instruments, some purchased with his wife's financial helps, others made himself through talent and passion. Spandri enjoyed replicating new scientific equipment as a fine instrument maker, whether from Italy or abroad. In a letter to Pianciani, he asked how he could replicate a new electro-medical instrument with "graded shocks" in his laboratory and whose explanations or figures he could not find anywhere. This apparatus, known as an induction electromotor by the Kemp brothers (figure 4), was a modified voltaic pile and was used in Rome at San Carlo Hospital by Giuseppe Derossi to treat his patients suffering from recurring or sporadic fevers. $^{21}$

Spandri was also commissioned to make instruments, which he did with the utmost competence. One of the first examples is his 1836 electromagnetic pendulum (figure 5), invented by Salvatore Dal Negro (1768-1839) from Padua and modified by Giovanni Federico Majer, meteorological observer of the Academy of Agriculture, Arts and Commerce of Verona. ${ }^{22}$

Spandri most likely started collecting scientific instruments around 1829 . In 1847, in a letter addressed to Pianciani, he wrote: "I have been working and studying for 18 years trying to put together a cabinet or a collection of machines for physics." 23 In the same letter, out of pride or vanity, Spandri also claimed the importance of his collection and explicitly affirmed that it was as good as that of the Royal High School of Verona. ${ }^{24}$ We have some historical evidence of his

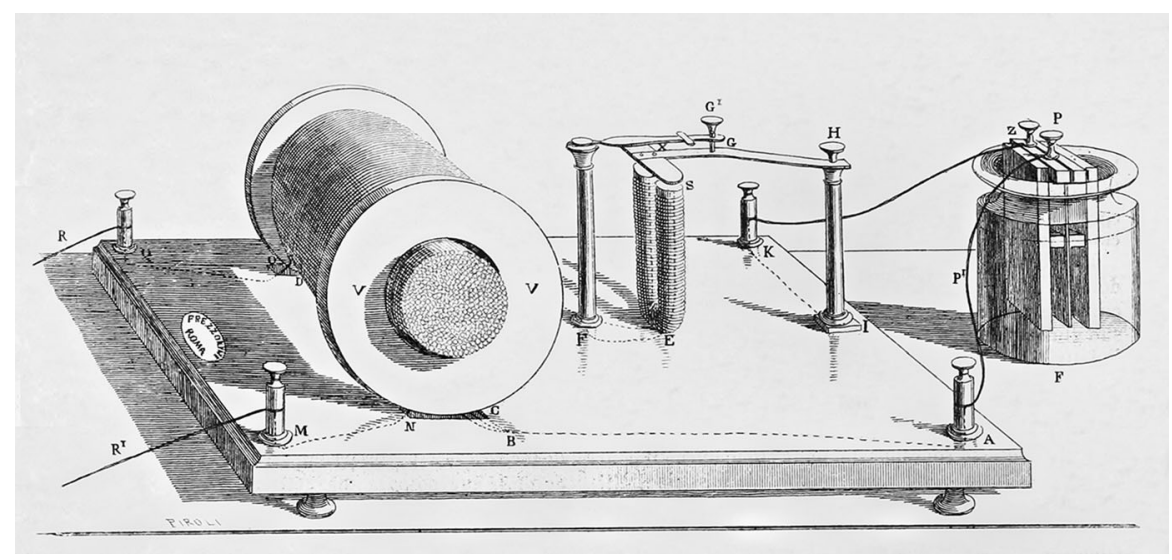

Fig. 4. The induction electromotor designed by the Kemp brothers to produce "graduated shocks." This electro-medical apparatus was built in Rome by the pharmacist Francesco Frezzolini. Source: L’album Giornale Letterario e di Belle Arti 12 (May 3, 1845), 76 
instrument collection. In a letter about terrestrial magnetism, dated December 26, 1844, the physicist Cesare Leopoldo Gazzaniga, from Desenzano, invited Zantedeschi to see Spandri's collection: "If in Verona you are going to visit Mr. Gaetano Spandri's beautiful Cabinet of Physics, where there is also Newman's Electro-Magnetic apparatus, you will be able to see the temporary magnet and the Grove's apparatus I was telling you about."25

Giovanni Antonio De Campostrini (1792-1846), President of the Academy of Agriculture, Arts and Commerce from 1842 to 1845, while briefly describing Spandri, highlighted how he had spent gold and silver to create his rich cabinet of physics. ${ }^{26}$ The discovery of an inventory of the machines, dated 1847 , allowed us to reconstruct the content of his cabinet. Before giving more information about this

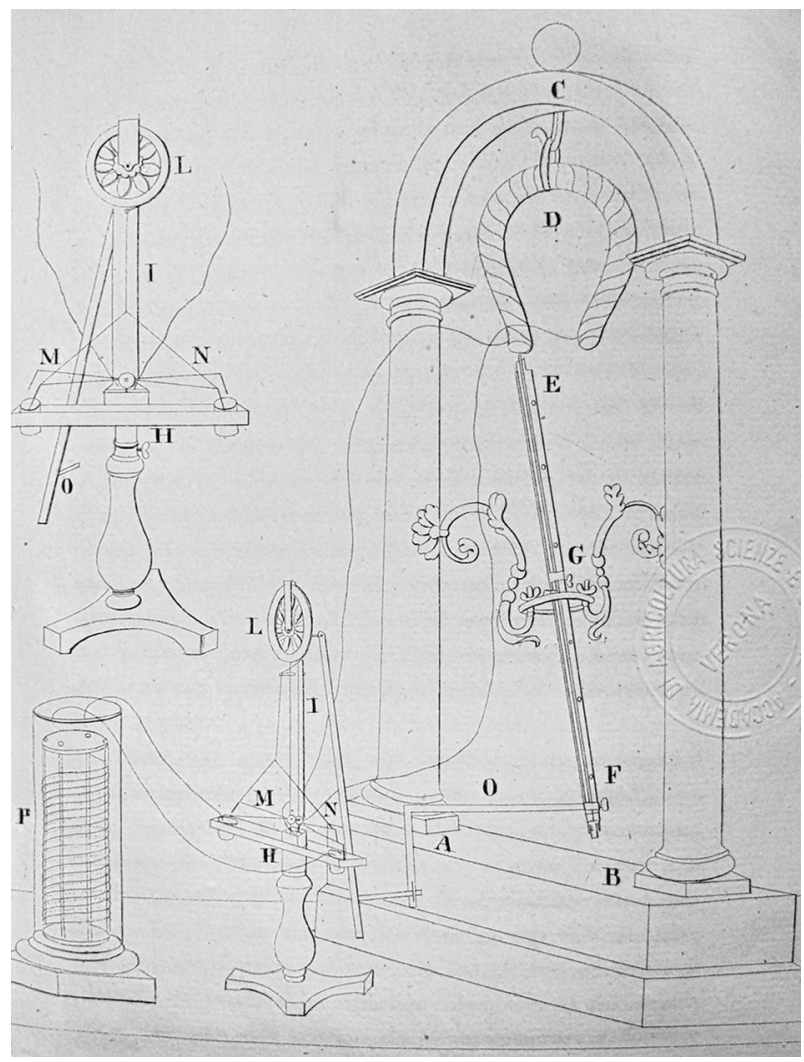

Fig. 5. Original designs of the electromagnetic pendulum invented by Dal Negro and improved by Majer under Spandri's scientific direction. Credit: Courtesy of Accademia di Agricoltura, Scienze e Lettere in Verona 
handwritten document, it is helpful to explain why Spandri drew up this inventory. Spandri had a complicated relationship with his only son, Giuseppe. The latter, against his father's will, left the priesthood, got married and moved away from his family, living first in Turin and then in Milan. Giuseppe undertook a career as a poet, historian, and scholar with little success and was disinterested in his family's property, particularly in the rich collection of scientific instruments. These personal events saddened Spandri. Aware he could not leave his scientific goods in his son's hands after his death, he decided—-together with his wife-to give his cabinet to the Jesuits.

This idea, which perfectly matched the educational activities of the Jesuits in Verona, is clearly expressed in one of his letters to Pianciani: "My specific purpose, besides taking care of what I was strongly keen on, was to put together a collection of machines that one day would be useful for the education of young people, and in doing so would give glory to God." ${ }^{27}$ The donation was recorded by notary deed on March 10,1847, by notary Giuseppe Donatelli. ${ }^{28}$ Spandri committed to giving

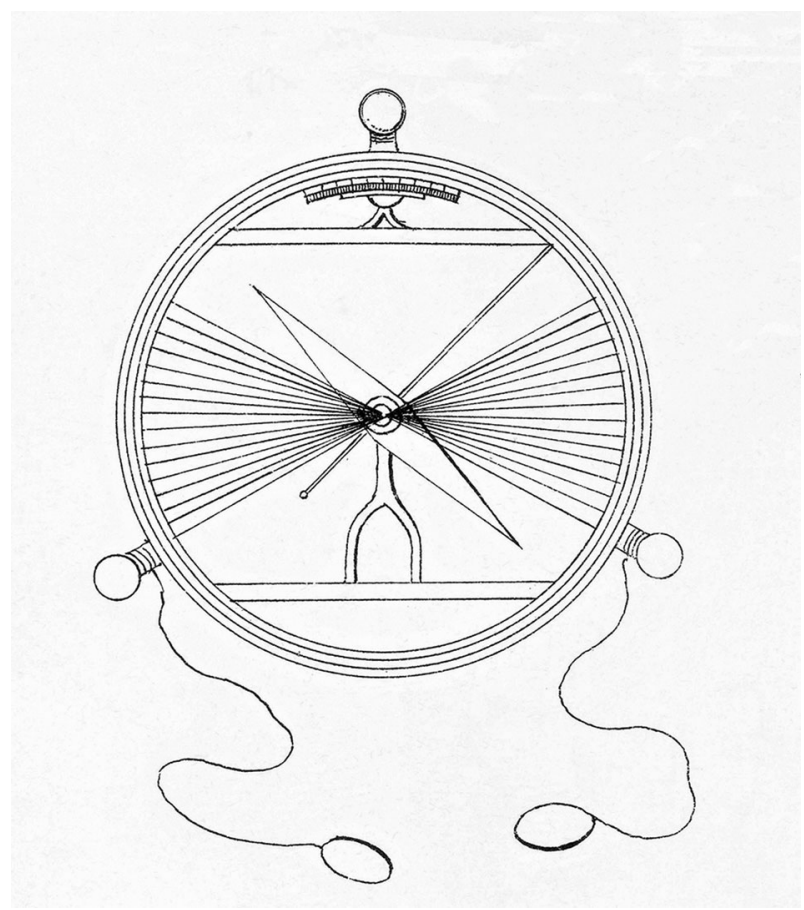

Fig. 6. Design of the crossed-wires multiplier galvanometer, invented in 1826 by Marianini. This piece was present in Spandri's 1847 inventory of scientific instruments 
up his entire collection with the possibility, if in the future they would have become of no use, that they might be given in part or totally "to the advantage of other Colleges of the same Company." In the donation clause, he reserved his right to the educational and scientific use of the collection "for the duration of his life." And indeed, still in 1856, he carried out experimental demonstrations with his instruments "to the young religious students of physics" of the Verona seminary. ${ }^{29}$ A copy of the deed and the complete list of the machines was given to the Dean of the Verona Jesuit College.

The transfer of his collection was not immediate: it happened only four months after his death, on February 3, 1860. ${ }^{30}$ The machines from the hall of physics and the astronomical instruments from his observatory were passed on to a high school run by the Jesuit Fathers in Verona and managed by Father Gaetano Tedeschi, a teacher of physics and astronomy. Some years later, the school was moved to Tyrol and Spandri's instruments went missing.

These events allow us to contextualize the rediscovered manuscript. The inventory of the machines was attached to the 1847 notary deed and is entitled "List of the Objects in the Cabinet or Collection of Physical Machines." The document briefly describes 122 pieces, but, overall, they were many more because the list omits annexes and accessories. ${ }^{31}$ It gives an accurate record of the type of instruments one could find at Spandri's. About half of the apparatus belonged to the branches of magnetism and static and dynamic electricity. Apart from Newman's magnetoelectric machine, which we will discuss later on, the following items in the inventory stand out: a large Dal Negro temporary magnet with nine accessories; several voltaic devices; some magic, Franklin, and sparkling electric squares; a Bennet electrometer; a Bohnenberger electroscope; Grove's and Wollaston's electric batteries; a crossed-wires multiplier galvanometer by the Italian physicist Stefano Marianini (figure 6); a couple of Ampère's stands; a Callan's machine for magneto-electric induction currents, which was awarded the gold medal by the Academy of Verona; and an electroplating apparatus with its medals (seven in total, made by Spandri himself), some of which are perfect replicas of the ones coined for the Meetings of the Italian Scientists held in Pisa (1839), Turin (1840), Florence (1841) and Padua (1842). Amongst the apparatus attributable to Zamboni, the inventory includes the "dynamic electroscope," a big electric clock and three perpetual electromotive devices kept under crystal bell jars, two of which are in the style of "columns plus pendulum" (figure 7) and one shaped like a "swing."

We have some historical references to the large electric clock and the dry piles. In a work from 1843, Zamboni writes that the electric clock is "owned by Mr. Gaetano Spandri in Verona, a very learned lover of natural sciences; it measures the average time precisely, only going off by about eight minutes over the course of the whole year." ${ }^{32}$ And in a letter dated 1856, in reply to Pianciani's question about the presence of Zamboni piles in Verona, Spandri maintains that the only working piles in town are the ones in his cabinet; he adds that his electric clock, powered by Zamboni piles, has been working for fourteen years. ${ }^{33}$ 
As for optics, beside some notable pieces by Giovanni Battista Amici (discussed later), we should mention a Ramsden telescope with six draw-tubes on a tripod, a telescope of the Viennese instrument maker Plössl with different oculars, several Brewster kaleidoscopes, a reflection phenakistoscope with six discs, and a camera lucida with a "graded black board" and mirror devised by the German anatomist Samuel Thomas von Sömmerring (1755-1830), which allowed the calculation of the magnification of microscopes.

Concerning astronomical geography, the inventory contains many celestial and terrestrial globes, a globe with the selenography of Bianchini's Venus spots, an armillary sphere, several astronomical solar clocks and a "macchina geociclica," that is, a Tellurium according to the Copernican system.

For meteorology, we notice the instruments made by Monza manufacturer Angelo Bellani (1776-1852). The inventory counts a differential thermometer and a photometer built by this skilled instrument maker, both Leslie-type, a Daniell hygrometer, a Réaumur mercury thermometer, and a "heat-collector."

Lastly, for pneumatics, at number 57 is a double-barrelled air pump with eleven accessories. In the inventory, the apparatus is listed as a "pneumatic machine with Professor Belli's improvement, so that vacuum arrives at a pressure of just one-

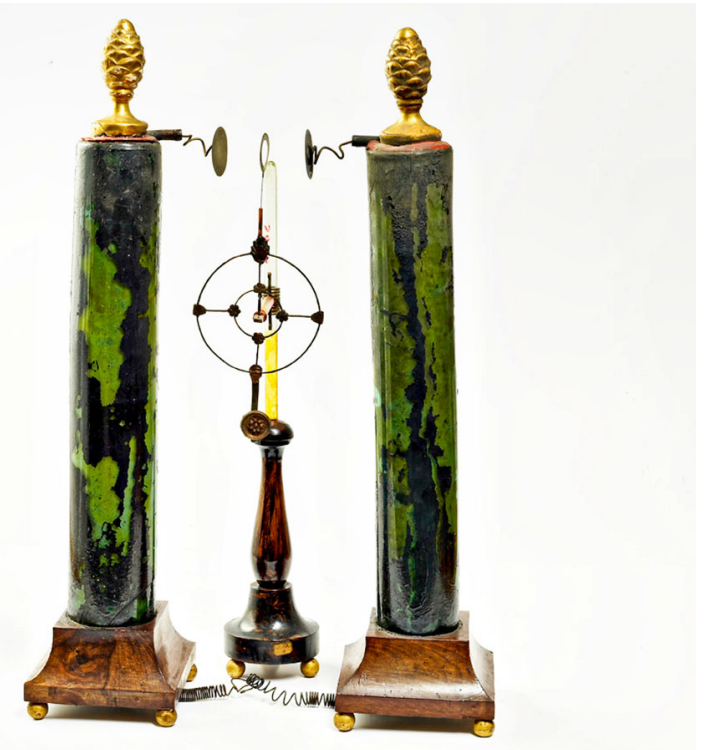

Fig. 7. Zamboni's Electrostatic pendulum or "perpetuum mobile," today preserved at the high school Scipione Maffei in Verona. The two dry piles, used as power supply, are concealed inside the columns. Credit: Courtesy of Liceo Classico Scipione Maffei in Verona 


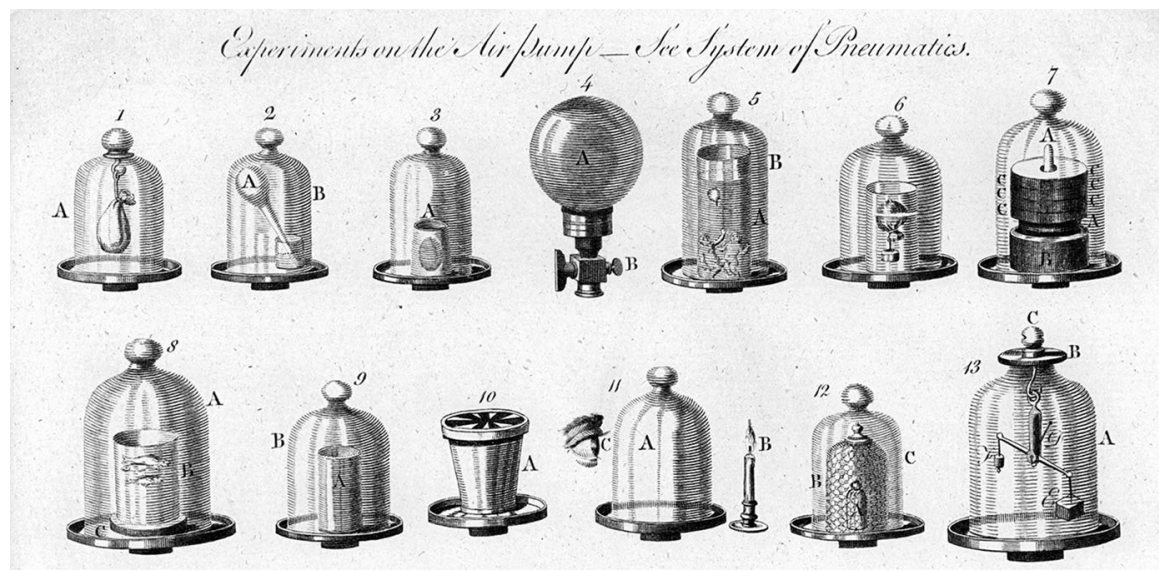

Fig. 8. Vacuum experiments from a late eighteenth-century print. The experiments indicated with numbers 7 (force of the bladder) and 8 (fishes in the water) are those experimented by Spandri. Credit: Roberto Mantovani's private collection

third of mercury line." It was a typical double-barrel brass air pump for vacuum having a "portable crystal plate reinforced in brass with a pedestal and a tap." It included five crystal bell jars of the open, closed, and reinforced type, the last with a manipulator or a sliding brass rod to operate from the outside; some maintenance mechanical wrenches; an air-pump gauge; apparatus for experiments in vacuum under an exhausted receiver, namely the expansive force of a sealed bladder (subjected to lead weights) and the behaviour of live fishes placed in water (figure 8).

From a mechanical point of view, the main innovation of this air pump was a special pneumatic air tap devised in 1827 by the Italian physicist Giuseppe Belli (1791-1860) who, thanks to appropriate changes of the connections between the barrels and the plate, significantly improved the machine's rarefaction. Using this machine, Spandri conducted experiments concerning phosphorous burning in contact with iodine in a vacuum. He came up with the idea while reading a 1833 memoir by Gazzaniga in the Annals of Sciences of the Lombard-Venetian Kingdom. ${ }^{34}$ At the end of the abstract, written to validate Gazzaniga's entrance as an honorary member of the Academy, Spandri added: "Then, thanks to my pneumatic machine with Belli's improvement, I tried to make this phenomenon also happen in a vacuum, where the remaining pressure was almost half a barometric line" (figure 9). ${ }^{35}$ 


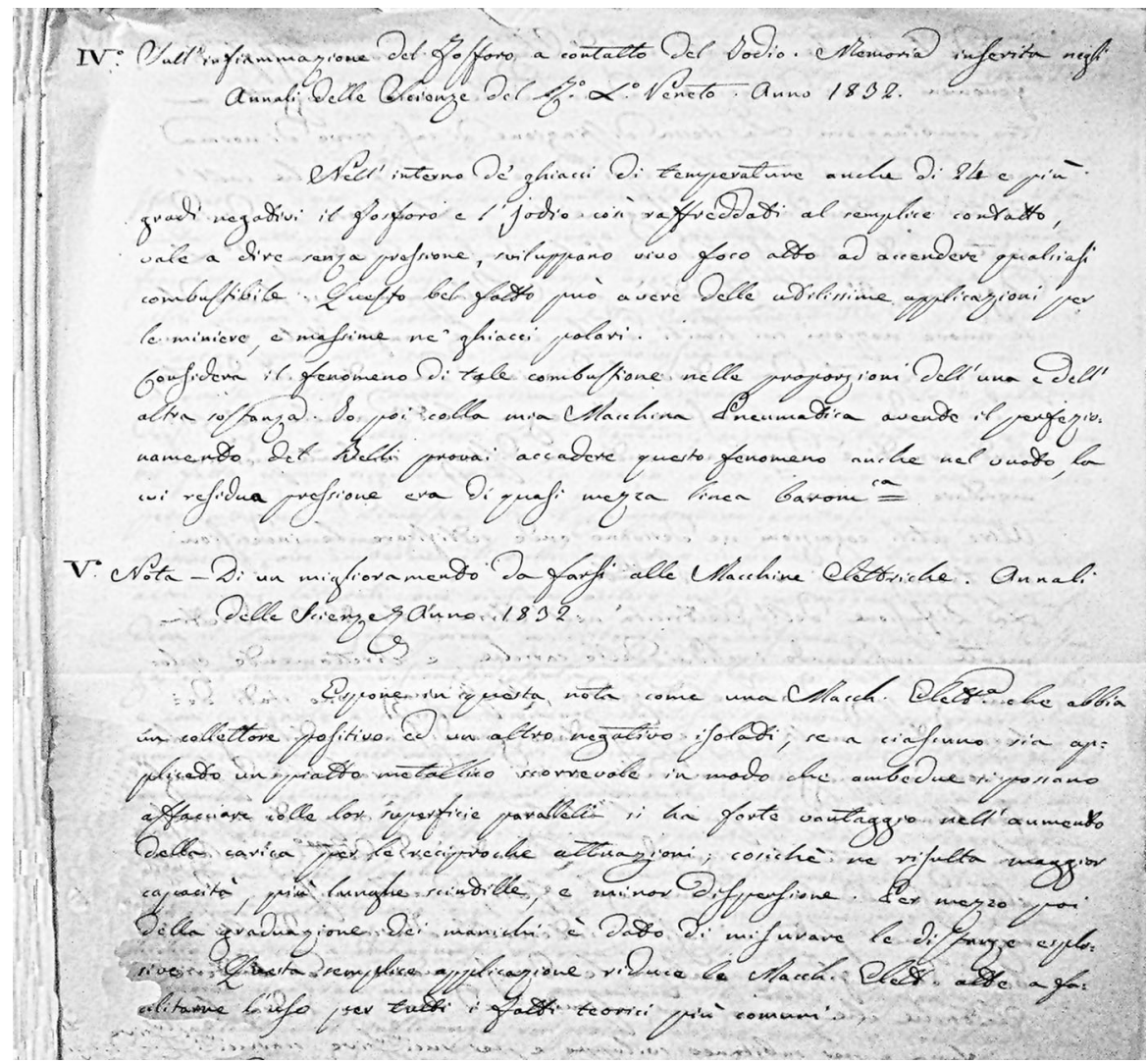

Fig. 9. Spandri's hand-written summary of the memory written by Gazzaniga entitled "On inflammation of phosphorus in contact with iodine." Credit: Courtesy of Accademia di Agricoltura, Scienze e Lettere in Verona

\section{Newman's Machine}

At number 56 of the 1847 inventory is a brief description of a powerful and uncommon Newman's magneto-electric machine, with two batteries of bent-bar magnets (both horizontal and vertical) and all its accessories. ${ }^{36}$ The story of this machine is intertwined with its introduction and spread in Italy. As noted above, Spandri's relationship with Zamboni allowed him to remain current on scientific news from abroad and the latest apparatus. When one of the earliest electromagnetic generators, devised in England in 1833 by the American engineer and inventor Joseph Saxton (1799-1873) and built by John Newman (figure 10), one of the best instrument makers in London, arrived in Italy, Zamboni informed Spandri 


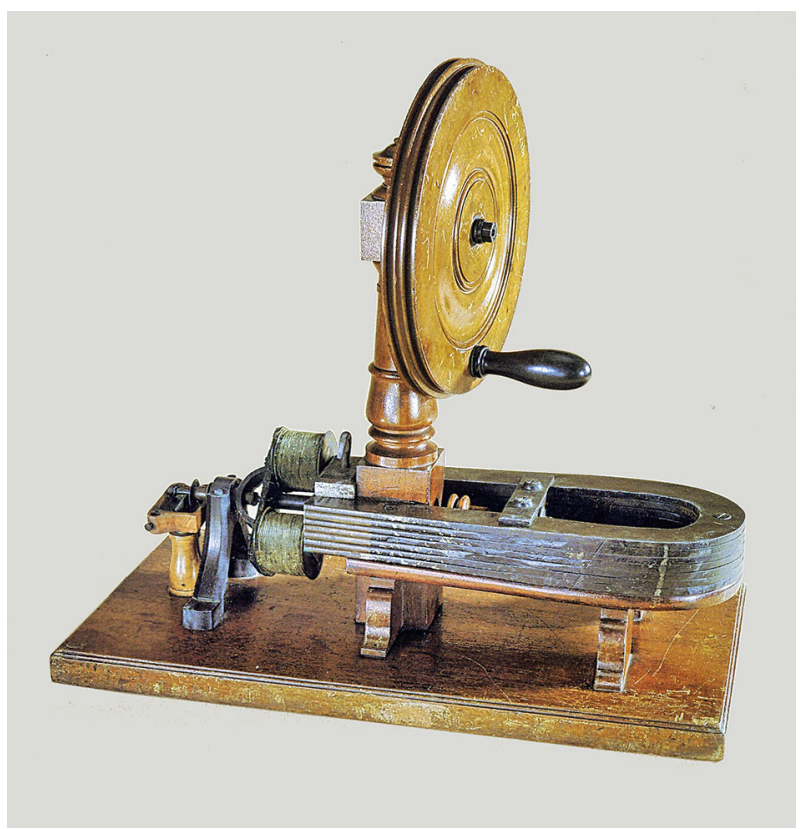

Fig. 10. Magneto-electric machine, Saxton type, signed "J. Newman Regent St. London," preserved in the King George III Collection, Science Museum, UK. Source: Alan Q. Morton and Jane A. Wess, Public \& Private Science. The King George III Collection (Oxford: Oxford University Press, 1993), 625. Credit: Courtesy of Oxford University Press

and asked him to duplicate it. ${ }^{37}$ The episode testifies to Spandri's role in disseminating this peculiar apparatus in Italy. Zamboni found out about the new device while reading an article by Pianciani, teacher of physics, natural history and chemistry at the Jesuit Roman College in Rome. Pianciani can be credited for the acquisition of the first Newman machine in Italy, ${ }^{38}$ and for carrying out a series of experiments with it, ${ }^{39}$ also the first in Italy, as his most famous pupil, Angelo Secchi (1818-78), recalls. ${ }^{40}$

These experiments were published in 1836 in the Giornale Arcadico di Scienze, Lettere ed Arti of Rome. ${ }^{41}$ Zamboni read Pianciani's paper and asked Spandri the courtesy of writing on his behalf to the professor in Rome to check the possibility of reproducing Newman's machine in Spandri's laboratory. The idea would prove impracticable because of the complexity of conveying the request via letter. The story has been reconstructed thanks to handwritten documents at the Academy of Sciences, Letters, and Arts of Verona, and most of all to a series of (unfortunately incomplete) letters between Spandri and Pianciani, which recently resurfaced at the Archives of Pontifical Gregorian University. ${ }^{42}$ 


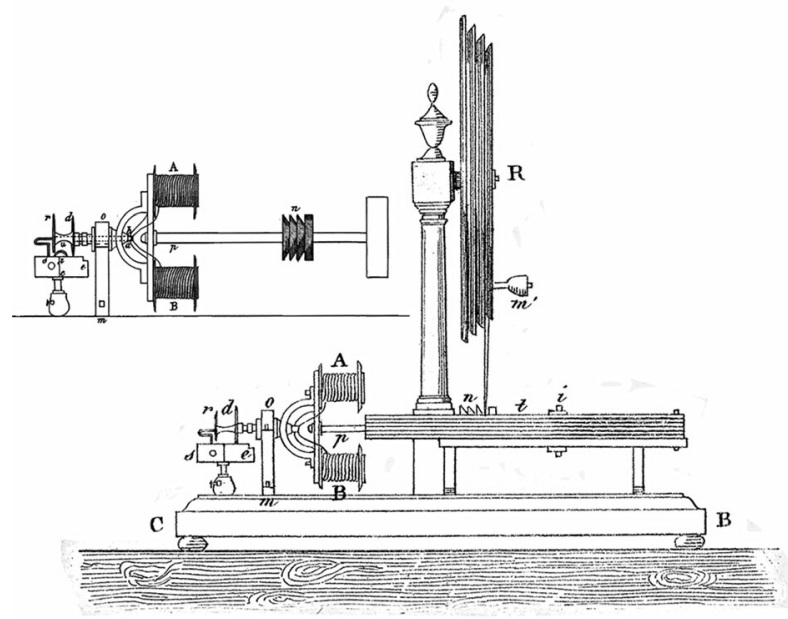

Fig. 11. Drawings in axonometric and orthogonal projection of Newman's machine built by the Lusvergh brothers for the cabinet of physics of the Roman Archiginnasio headed by Saverio Barlocci. Source: Saverio Barlocci, Lezioni di Fisica Sperimentale, 2nd ed., vol. 2, pts. 6-8 (Roma: Tipografia Dell'Ospizio Apost., 1841), tav. 4, figs. 161-62

In the first of these letters, dated September 28, 1837, Spandri wrote that, as soon as Professor Zamboni read the essay on magneto-electric induction phenomena containing the description of Newman's machine, he felt the need to have an identical one for the cabinet of physics of his school in Verona, and asked him to assume responsibility for its construction. ${ }^{43}$ Of course, Spandri accepted and reserved the possibility of making replicas of a few more machines to benefit his physical cabinet and the seminary of Verona. He requested from Pianciani measurements of all the "different parts" the machine he owned, precisely, the dimensions of the steel bent magnets, which were part of the instrument, the best way to magnetize them, the dimensions of the coil, of the copper wires, the number of the windings in the two coils, the materials, the wire connections, and much other minor information. Spandri then wanted to know how the switch worked and asked Pianciani for a suggestion on modifying the machine to make it more efficient and pronounced in its visual effects.

The information Pianciani gave through letters was not enough to proceed with construction, which turned out to be quite complex. Reading the letters clarifies the difficulties in learning the building details and the dimensions of all the machine's components through a remote conversation. As a result, the Veronese physicists gave up on the idea of making the machine in Verona. They decided that 


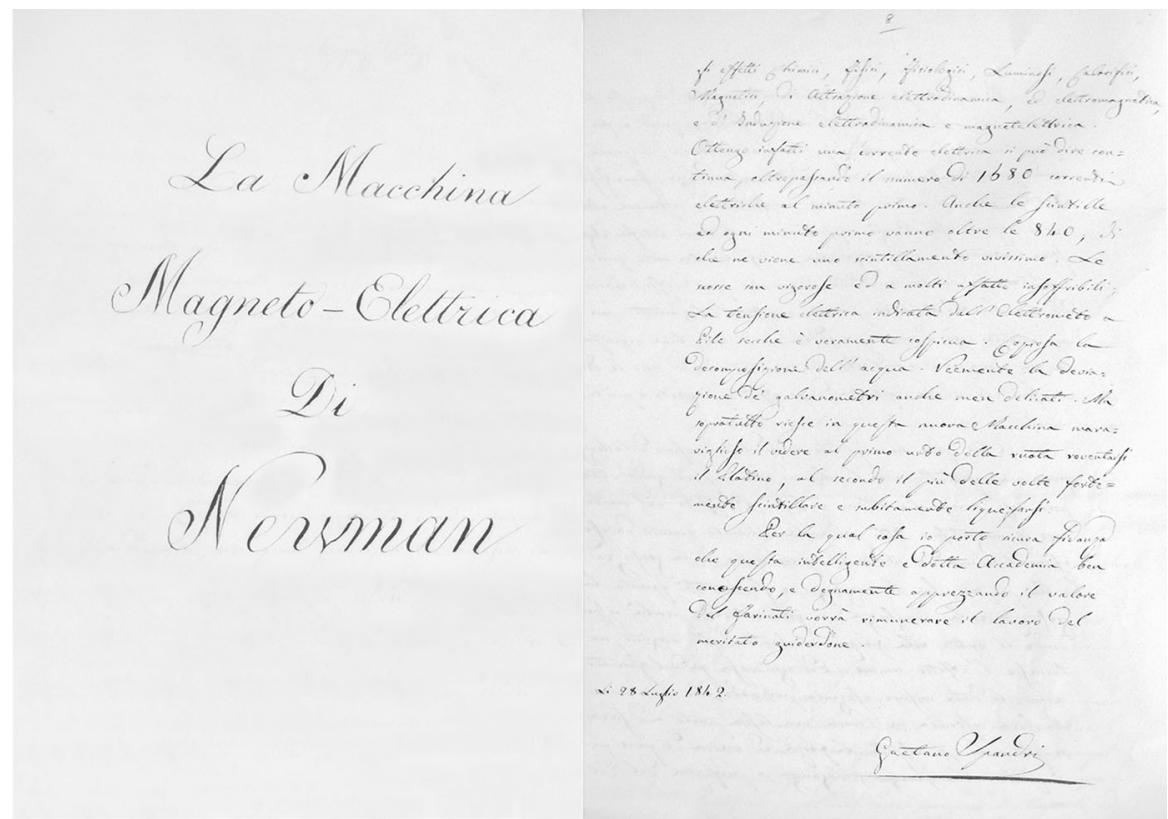

Fig. 12. Title and last pages of the handwritten memory written by Spandri on Newman's machine. It is dated July 28, 1842, and is kept in the archive of the Academy of Agriculture in Verona. Credit: Courtesy of Accademia di Agricoltura, Scienze e Lettere in Verona

the only way to have it was to buy it in Rome from Pianciani's trusted instrument makers, the brothers Domenico and Luigi Lusvergh; in the meantime, the latter had already experimented with making a replica of the machine by request of Professor Saverio Barlocci (1777-1845) who had ordered it for the cabinet of physics of the Roman Archiginnasio (figure 11). ${ }^{44}$

The order took quite long, but, from a second letter dated May 12, 1838, we learn that it was ready for shipping on that date. ${ }^{45}$ Spandri complained about the Lusverghs brothers' behaviour because they had not agreed to equip the machine with all the accessories he requested, in particular, the "platinum thread," an accessory that permitted "display" of a calorific effect of the "magneto-electric current." ${ }^{46}$ From some documents of the Academy of Sciences, Letters, and Arts of Verona, which served as a sort of guarantor of scientific innovations for the Austrian authorities-Verona was at the time part of the Austrian Empire-we learn that the machine arrived in Verona in 1838.

In a letter dated June 12, we read that the Imperial and Royal Provincial Finance Office asked for an opinion about the "novelty of a Newman's electromagnetic machine" for which Spandri had requested an import duty tax 
exemption. To straighten out the problem, a board within the academy was created with Zamboni, Jacopo Bertoncelli, and Giulio Sandri as commissioners. They expressed the opinion that the coming machine was "brand new" and the first one brought to the "Austrian Monarchy." 47

The Lusvergh's machine arrived at the physics cabinet of the School of Verona. Spandri was able to study and duplicate it into two new models, which he completed within two years. ${ }^{48}$ The first model increased the cabinet of physics of the Episcopal Seminary of Verona, the other Spandri's private collection. In these operations, he did not just duplicate the apparatus from a mechanical point of view, but tried to implement some modifications, also following some advice he had received from Pianciani. ${ }^{49}$

The practice of modifying scientific apparatus from abroad was standard among Italian physicists of the first half of the nineteenth century. For this purpose, they were helped by the figure of the "machinist," an institutional technician who skilfully and professionally maintained, repaired, and manufactured scientific instruments in the cabinets of physics; in his absence, physicists generally relied on some trusted instrument maker. Pianciani himself, while carrying out his experiments in the cabinet of physics of the Roman College, modified the Newman machine he owned with the help of the Lusvergh's mechanical skills. ${ }^{50}$ According to this modus operandi, Spandri modified Newman's machine for his own physical cabinet and provided it with both horizontal and vertical magnetic bars. ${ }^{51}$

With such changes, he presented the apparatus at the meeting of August 4, 1842, at the Accademia d'Agricoltura, Arti e Commercio of Verona, reading a memoir dated July 28, 1842. This handwritten memoir (figure 12), now kept in the archives of the Verona Academy, gives us further and more helpful information on the machine. ${ }^{52}$ For its construction, Spandri relied on a trusted maker, Agostino Farinati, who had helped him with other apparatus.

The memoir is divided into a historical excursus on Ørsted's, Ampere's, and Faraday's electromagnetic studies leading to the invention of the "magneto-electric machine," and a description of the stages of production of the machine, the changes, and the obtained final effects. Regarding this latter, here is a long but meaningful extract:

as I trusted Farinati's proven mastery, I did not settle for just an accurate copy of the machine I had bought but mostly attempted to ensure that the newly built one gave stronger and more luminous effects by increasing its dimensions a little. To this purpose, I have somewhat increased the measures of the horseshoe magnetic battery, but, above all, I had an eye for obtaining a level of tempering of the steel that would be optimal for maintaining magnetism. I have then calculated the volume of the ductile iron cylinders, the size of the connecting plate, and finally, the width and length of the metal wires so that, responding to the increased force of the magnets, we could have the maximum effect. And everything has been excellently made by Farinati, according to the 
given measures, so that the new machine built in Verona is up to any standard, concerning both the force and the energy of the phenomena and the quality, elegance, and perfection of the work. Actually, with this new magneto-electric machine, that I hope lovers of the elegance of mechanical works will not regret, I am conspicuously obtaining all the effects of the Volta apparatus: I mean the chemical, physical, physiological, luminous, calorific, magnetic effects, of electro-dynamic and electro-magnetic attraction, and electro-dynamic and magneto-electric induction. In fact, I am getting an electric current-which may be considered direct-surpassing the number of 1680 electric currents per minute. Also, the sparks get beyond 840 every minute; hence a very vivid sparkling. Shocks are vigorous and by any means insufferable to many. The electrical potential difference marked by the dry-pile electrometer is notable. The water-splitting copious. The deviation of the galvanometers, though not delicate, strong. But above of all, with this new machine we do see the wonder of platinum heat up at the wheel's first stroke, at the second most of the times strongly spark and immediately liquefy. ${ }^{53}$

\section{Amici's Microscopes}

From the 1847 inventory and some letters, we learn that Spandri owned some microscopes built by Giovanni Battista Amici (1786-1863), a noted Italian scientist, astronomer of the Grand Duke of Tuscany, and one of the most renowned European microscopes makers of the first half of the nineteenth century. The Estense University Library in Modena holds the (incomplete) correspondence between Spandri and Amici in 1843-52. It consists of twelve letters sent by Spandri and some drafts of Amici's answers. This correspondence lets us retrace, with some details, the purchase of a couple of microscopes. From a letter dated January 19, 1843, we learn that in May 1835, Spandri bought a small vertical achromatic microscope from Amici, thanks to his friend Giovanni Federico Majer, who had ordered it on his behalf. With this "excellent instrument," which cost 260 francs, ${ }^{54}$ Spandri was able to "establish a good number of subtle observations very successfully." ${ }^{\text {S5 }}$

Generously, Spandri made this microscope available for research at the Academy of Agriculture. He used it to collaborate with G. Antonio De Campostrini, the Academy President, on a study of silkworms' eggs and in drawing tables supporting the scientific survey. ${ }^{56}$ In 1843 , Spandri bought a second Amici microscope, far more powerful than the first. It was the "great horizontal-vertical achromatic catadioptric microscope," the most expensive model Amici offered because, besides working as a common dioptric microscope, it could be transformed also into a catadioptric or reflecting microscope (figure 13). The instrument cost one thousand francs, ${ }^{57}$ a remarkable price for the time if we consider that a fairly large apparatus such as a "double-barreled vacuum pump 

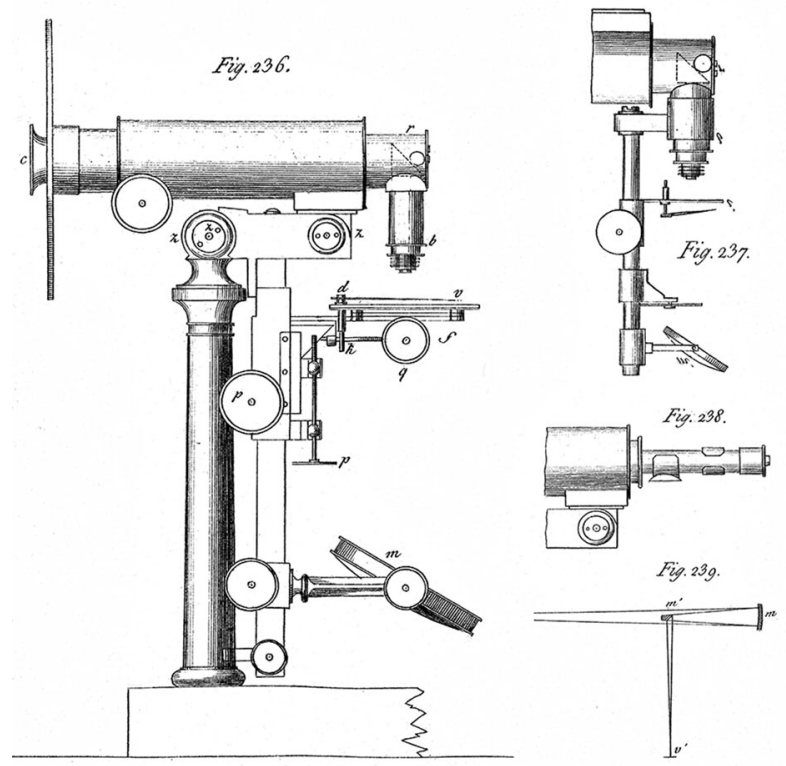

Fig. 13. Amici's achromatic microscope, commercialized in France by C. Chevalier. This microscope could be positioned horizontally or vertically and transformed into a reflecting microscope. Source: Claude Servais Mathias Pouillet, Elementi di Fisica Sperimentale e di Meteorologia. Con note e giunte di L. Palmieri, 3nd Italian ed., vol. 3 (Napoli: Puzziello TipografoLibraio, 1840), tav. 25

with thick-walled glass cylinders" mounted on a small walnut table, cost 600 Austrian lire in the same period. ${ }^{58}$

Spandri asked Amici to accessorize the microscope with as many oculars and lens as possible, some camera lucidas (Amici included two, which could be applied to the oculars) and eventually some valid test objects, namely "the most delicate and curious microscopic objects one could observe." Amici suggested "one of his most modern microscopes" equipped with "a crystal prism to totally reflect horizontal light inside the tube," "plane and concave glass mirrors" for the lighting and four oculars and nine achromatic lenses through which one got "many different enlargements for the transparent and opaque objects." ${ }^{59}$ The order was placed on January 29. Later, Spandri requested the portraits of Leopoldo Nobili and Amici himself as part of the same order.

Although they agreed on two months, it was delivered many months later, due to accidents linked to Amici's relatives' health problems and troubles with customs. In the letters, Spandri justified the purchase saying that it could fully satisfy his needs and "be of notable service" to "the many learned enquirers" working at 
the Academy of Agriculture. ${ }^{60}$ The microscope, tidily placed in a box, reached its destination on September 16, 1843, together with a technical file with detailed instructions for its correct use and Leopoldo Nobili's portrait. This technical file, rich in operating information about the instrument that Amici generally attached to his orders, ${ }^{61}$ was found in the Amici fund deposited in the Estense University Library of Modena and published in 2002. ${ }^{62}$ In subsequent letters, Spandri expressed his full appreciation for the instrument and quoted the naturalist Sandri's and Zamboni's enthusiastic comments. In a letter dated October 1, 1843, he wrote:

after practising with its instructions, in front of some of my colleagues, I assembled it confidently; and used the test-objects you gave me, and I cannot describe the astonishment we all felt in seeing an apparatus with so many qualities. Visual clarity, you cannot wish for more; precision of contours, you can distinguish the subtlest parts; perfect achromatism, it shows us the actual colours of the objects; copy of enlargements, to the observer's complete satisfaction: and then the delicate work of the micrometer screws performed with such detailed precision; the ready and accurate service of the camera lucidas; the clear brightness of many lenses; and the total of the working perfection of all its several parts, all this makes it an instrument of priceless value."63

In subsequent years, the apparatus continued to work and to increase its accessories. In 1851 Amici sent a new lighting system that was a "substage apparatus" equipped with a plano-convex condenser lens to illuminate transparent objects better. ${ }^{64}$ The correspondence between the two scientists ended on September 10, 1852, with a letter in which Spandri thanked Amici for his memoir read at the Academy of Georgofili of Florence on September 5, 1852, on the microscopic observations of grape disease; ${ }^{65}$ he updated him on the fact that also at the Academy of Verona, thanks to his "Great microscope," they were carrying out researches on that disease affecting grapes in the Venetian and Lombard areas.

\section{The Academy of Verona}

In December 1838, Spandri became a member of the Academy of Agriculture, Arts, and Commerce, for which he carried out a variety of tasks, personal initiatives, and studies. ${ }^{66}$ One of his tasks was to examine scientific memoirs submitted to the Academy, prepare reports on them, and notify other members and the faculty members of the Society. This was the case of some memoirs sent by the honorary Member Angelo Bellani from Milan, ${ }^{67}$ and of a booklet sent to the society by the Venetian noble Giovanni Minotto regarding the economical use of fuels and the possible advantages of heated air as motive power. ${ }^{68}$

Other times, Spandri performed tasks the academy requested of him. In 1840 he was asked to study "unhealthy waters" in wells in the countryside south of Verona: the academy wanted to verify physicians' opinions that they were responsible for 
fevers affecting people living there. ${ }^{69}$ A chemical analysis of the waters was filed at the academy on December 10,1840; it was not published, but rather read in the meeting of February 25, $1841^{70}$

Spandri also engaged in personal initiatives to improve the academy's scientific activities. He declared his availability to perform delicate experiments on behalf of academy members, offering his rich physical cabinet, for instance for a study by the Veronese mathematician Pietro Maggi (1809-54) on the thermal conductivity of magnetic bodies. ${ }^{71}$

Spandri also nominated Cesare Leopoldo Gazzaniga, professor of physics and natural history at the Istituto Filosofico Privilegiato of Desenzano, to honorary membership of the academy. He prepared a note about his publications (mainly on electricity and magnetism) and a list of the memoirs, and a summary of each. ${ }^{72}$ With his new role as honorary member, Gazzaniga made his meteorological observations available to the academy.

\section{Meteorology}

Spandri became interested in meteorology around 1839-40, when he met Gazzaniga's new partner, who had been collecting meteorological data in Desenzano. ${ }^{73}$ Spandri strove to make the meteorological data available to the Academy of Verona: data which were collected, out of region, by Gazzaniga's partner. Between 1838 and 1839 the academy had found a new location to carry out meteorological observations inside the academy's Botanical-Agrarian Garden. For the occasion, they planned a new schedule of meteorological observations. An academy board chaired by Zamboni produced a schedule demanding that Giovanni Federico Mayer, meteorological observer appointed by the academy, measure the barometric, hygrometric, thermometric, rainfall and magnetic kind daily. ${ }^{74}$ In 1841, Mayer fell ill, and the academy replaced him, temporarily, with Jacopo Bertoncelli. ${ }^{75}$ In 1842, after De Campostrini became director of the academy, Bertoncelli was appointed director of the Botanical-Agrarian Garden; his position of meteorological operator was given to Zamboni, who held it until the end of 1845, while still taking advantage of Bertoncelli's cooperation.

On January 8, 1844, a press release arrived at the academy, sent by Vincenzo Antinori, director of the Imperial and Royal Museum of Physics and Natural History of Florence. It reported that, on the Grand Duke of Tuscany's initiative, the Museum of Physics of Florence would start collecting the "observations of meteorology" carried out in Italy to make up an Italian Central Meteorological Archive. The observations had to be accompanied by the places they were carried out and by the instruments employed; the academy accepted the request. Through its secretary of the Academy, Count Giovanni Scopoli, it asked Spandri to send Verona's and Desenzano's meteorological observations, carried out in 1843 by Zamboni and Gazzaniga respectively, to Florence. ${ }^{76}$ Scopoli also ordered that, 
from then on, the Academy meteorological observations had to be sent to Antinori each year.

After Zamboni died in 1846, the meteorological observer role returned to Bertoncelli until his death in August 1848. Meteorological data collection then continued thanks to Spandri's availability; however, he had to wait until January 1849 to receive the assignment officially. At the January 18, 1849, session in substitution of the deceased Bertoncelli, the Academy's Perpetual Secretary Giovanni Scopoli appointed Spandri "meteorological observer" for the three-year period 1849-51. In that year, Spandri, in the Memoirs of the Academy, published the meteorological observations collected in $1848 .{ }^{77}$ In this work is a concise description of how Spandri acquired the daily meteorological data:

I systematically collect them three times a day, the first at the rising sun ... the second as the sun descends, because when the temperature is at its highest and its lowest, there is no need of my presence, as I have got two excellent maximum and minimum thermometers ${ }^{78}$ that is Bellani's and Rutherford's.... The third time around midnight. I display the said instruments (thus following the example of that great man who first was appointed, in 1780, by this prestigious Academy, as its Meteorological Observer, the immortal Cagnoli) at a window of my house, 8.50 meters from the ground and far from lateral reflections. ${ }^{79}$

This extract reveals that, from September 1848, he had moved data collection from the Botanical-Agrarian Garden to his private home observatory. Spandri held his job as observer for the academy for six consecutive years until 1853, when he was replaced by Bartolomeo Bertoncelli, who brought the place of measurements back to the Botanical-Agrarian Garden. ${ }^{80}$ During his six years of activity, Spandri also started filling out a meteorological bulletin for the city of Verona. The data were daily published in the local newspaper, and a public report was printed yearly among the memoirs of the academy. ${ }^{81}$

\section{The Reports and the Academic Memoirs}

The Academy of Agriculture of Verona's archives preserve many of Spandri's reports and handwritten memoirs, most of which remain unpublished and little known. Some deal with natural sciences, others with electro-chemistry, electricity, magnetism, and scientific instruments. As noted above, the Academy would ask Spandri to write reports consisting of extracts or summaries of the scientific memoirs the academy used to receive as donations. Among these reports, particularly relevant are those related to the memoirs on the breeding of silkworms by academy member Angelo Bellani. The academy archives keep four reports written by Spandri in 1842-44. ${ }^{82}$ Other interesting reports were those summarising the results of several works by honorary member Cesare Leopoldo Gazzaniga. After publishing them in the Annals of the Sciences of the Lombard-Venetian Kingdom, Gazzaniga proposed them again to the academic members of Verona. The topics 
at issue dealt with the "mutual influence of each eye in seeing distinct and clear" $(1843,)^{83}$ and a study on geomagnetism (1847). ${ }^{84}$ Lastly, there is a report written together with Paolo Vignola and Bartolomeo Bertoncelli and read on February 23, 1854 , on "electric light." 85

From 1842 Spandri developed an interest in electroplating, an electrochemical technique invented some years earlier that permitted the reproduction of small objects: a thin metal layer was deposited on a non-conducting plate that acted as the cathode of an electrolytic cell. As noted above (ref. 18), Zamboni had informed Spandri about the new electro-chemical process, thanks to a booklet he had received from Bertoncelli. The topic aroused Spandri's curiosity, and he decided to study the new procedure with his partner Bertoncelli. They jointly presented a handwritten memoir on the topic, which is still kept in the archives of the academy, and which was read in a public meeting on May 12, $1842 .{ }^{86}$

The memoir retraces the history of this "new art" from its first applications proposed by Alessandro Volta with his electric battery to the invention of the German mathematician and physicist Carl Gustav Jacobi (1804-51). The memoir also afforded the opportunity to show the members some electroplating samples and reaffirm the benefit this invention could bring to the art of copper engraving. Spandri and Bertoncelli showed a copy of a medal owned by Gazzaniga, whose coinage was ordered by King Charles Albert of Savoy in September 1840 in Turin, on the Second Meeting of Italian Scientists, which Gazzaniga himself attended. ${ }^{87}$ The mould of the medal was made entirely with Spandri's electroplating apparatus, described at number 116 of the 1847 inventory.

As we learn from a letter dated August 5, 1842, "88 "the electroplating samples" presented in the 12 May meeting were, in the same year, displayed at the academy's triennial public competition of industrial objects. The practice of presenting memoirs on valuable scientific instruments and experiments was widely favoured within the academy because of the concrete possibility that the proponents had of competing subsequently for favourable awards and judgements. Every three years, the academy organized a public display of industrial items where the worthiest and most innovative were evaluated and awarded. A board made up of the academy members who expressed judgments and decided the prizes. Spandri took part in the contests several times, almost always presenting handwritten memoirs supporting the displayed scientific instruments.

Besides the memoir on Newman's machine, the academy archives hold two unpublished, handwritten memoirs, one on Faraday's multiplier and the other on Callan's induction coil. The multiplier was an electric machine Spandri called "Faraday's multiplier"; he read the memoir at the academy session of August 7, 1845 and displayed the apparatus at that year's prize competition. The other memoir concerns "Callan's machine" (figure 14), an induction coil like the one devised in 1836 by the Irish priest Nicholas Callan (1799-1864). This induction coil was modified in 1840 by the instrument maker Carlo Dell'Acqua, at that time machinist at the S. Alessandro High School in Milan. It was called "induction coil 


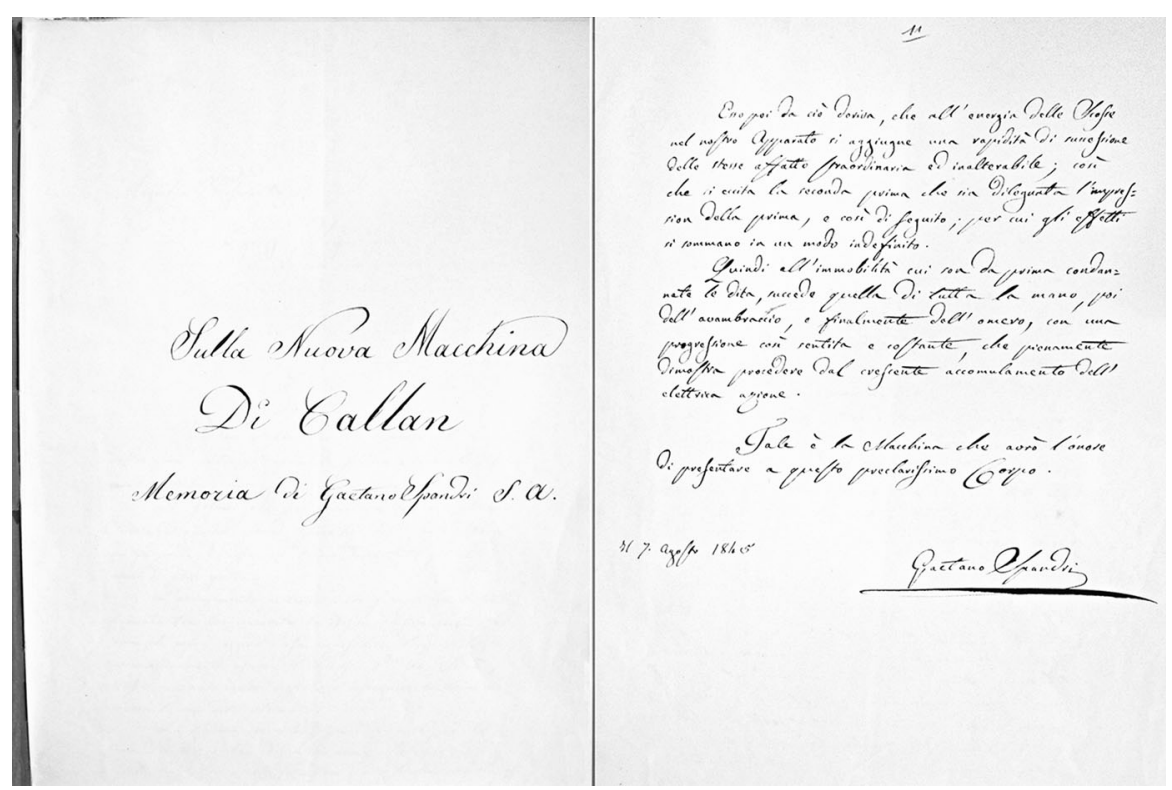

Fig. 14. Title and last pages of Spandri's handwritten memoir on Callan's new machine. It is dated August 7, 1845 and kept in the Archive of the Accademia di Agricoltura in Verona. Credit: Courtesy of Accademia di Agricoltura, Scienze e Lettere in Verona

with a rotating voltaic magnet," and Zamboni had bought it in Milan from Dell'Acqua workshop to enrich the Cabinet of Physics of his Veronese high school.

The machine probably arrived in Verona in the first semester of 1845. Spandri had it duplicated by a young, trusted maker of his, Domenico Pigozzi, to enrich his physical cabinet. The official presentation of "Callan's electro-magnetic machine" took place with a memoir read on August 7, 1845, at the academy. ${ }^{89}$ In the following academic session of August 28, it was awarded a "gold medal of third size." 90 In the subsequent years this apparatus was carefully studied in Verona by the Stimmatini Abbot Vincenzo Vignola (1821-99) who found it faulty in the switch; after several attempts, he devised a new induction coil, which is today kept at the Museum of Physics "Antonio Maria Traversi" in Venice. ${ }^{91}$

\section{Concluding Remarks}

Spandri, a learned but amateur scientist, offers us a vivid account of how the scientific practices of a skilled experimenter and instrument maker were carried out in a medium-sized provincial town in northern Italy. The analysis of his rich 
private instrument collection, the study of his correspondence with Italian scientists, and his intense activity as a member of the local Academy of Agriculture provide us with a significant example of the scientific interests circulating in Italy in the mid-nineteenth century.

Like most scientists of his time, Spandri cultivated wide scientific interests, stimulated mainly by the requests and experimental needs of Giuseppe Zamboni. However, his most significant activities concerned the construction and practical use of scientific instruments, skills that were recognized, in various forms, by many interlocutors of his time. The analysis of these aspects is a valuable source of historical and scientific information. Exemplary, in this regard, is the story of Newman's machine which offers us valuable information on the spread of the first magneto-electric machines in Italy and makes us aware of a typical modus operandi of Italian scientific instrument makers in the first half of the nineteenth century. I refer to the practice, then quite common, of modifying scientific apparatuses to make them performing better in the eyes of the experimenters.

On this last point, it is important to highlight that, in those years, scientists worked mainly according to the methodological context of the "physics of the visible" or the "physics of observable phenomena," an experimental approach that preferred the amplification of the phenomenon rather than its measure. Mechanical modifications were generally aimed at obtaining more striking visual effects that would, later, highlight the correlations among the studied phenomena. ${ }^{92}$ From this perspective, Spandri was a typical exponent of Baconian physics. He worked within a theory devoid of calculations and measurements where the explanation of the phenomenon had to be completely "visual."

As a starting point, these activities presumed access to a good number of scientific instruments. Spandri's strong point was amassing a considerable collection apparatus and then using it to improve his experimental work and practical applications. Although lacking in theoretical knowledge, he combined excellent experimental capacity with deft construction skills and ingenuity in the search for new and more effective mechanical solutions. This mixture of conditions and abilities, certainly favorable and not common among nineteenth-century men of science, makes Spandri a particularly intriguing amateur scientist.

\section{Open Access}

This article is licensed under a Creative Commons Attribution 4.0 International License, which permits use, sharing, adaptation, distribution and reproduction in any medium or format, as long as you give appropriate credit to the original author(s) and the source, provide a link to the Creative Commons licence, and indicate if changes were made. The images or other third party material in this article are included in the article's Creative Commons licence, unless indicated otherwise in a credit line to the material. If material is not included in the article's Creative Commons licence and your intended use is not permitted by statutory 
regulation or exceeds the permitted use, you will need to obtain permission directly from the copyright holder. To view a copy of this licence, visit http:// creativecommons.org/licenses/by/4.0/.

Publisher's Note Springer Nature remains neutral with regard to jurisdictional claims in published maps and institutional affiliations.

\section{References}

${ }^{1}$ Ettore Righi, "Storia dell'Accademia di Agricoltura, Commercio ed Arti di Verona per il triennio 1857-58-59, Letta il 2 aprile 1868," Memorie dell'Accademia d'Agricoltura, Commercio ed Arti di Verona 46 (Verona, 1869), 414. All translations are by the author unless otherwise noted.

${ }^{2}$ He held the only one at the Accademia d'Agricoltura, Commercio ed Arti of Verona, where he was a meteorological observer for six years.

${ }^{3}$ Founded in 1768, it is still an active institution under the name of Accademia di Agricoltura, Scienze e Lettere di Verona.

${ }^{4}$ Gazzaniga was from Pavia and was a Professor of Physics and Natural History at the Philosophical Institute of Desenzano.

${ }^{5}$ Francesco Zantedeschi, "Di alcune modificazioni fatte alla macchina magneto-elettrica di Newman e dei speciali esperimenti eseguiti con essa," Annali delle Scienze del Regno LombardoVeneto 12 (1842), 74.

${ }^{6}$ Giambattista Pianciani, Elementi di Fisico-chimica di G. B. Pianciani della Compagnia di Gesù professore del Collegio Romano. Uno de' XL della Società Italiana delle Scienze, 3rd ed., vol. 2 (Roma: Tipografia Marini e Compagno, 1844), 71; a year later, he gave a second opinion: "a very intelligent and learned person whose kindness was no less known to me than his ability in experimenting," see Giambattista Pianciani, "Termoelettricismo. Del freddo prodotto dalle correnti elettriche," Raccolta di Lettere ed altri scritti intorno alla Fisica e alle Matematiche compilata dal Dott. C. Palomba 1 (1845), 15.

${ }^{7}$ The house is close to Palazzo dell'Orologio (Clock Tower) where the Veronese mathematician and astronomer Antonio Cagnoli (1743-1816) lived.

${ }^{8}$ The reason for this interest in astronomy is well-known. In 1849, Bon Brenzoni met the Scottish scientist Mary Somerville Fairfax (1780-1872), author of the work On the Connection of the Physical Sciences, and was fascinated by her. In her honour, she wanted to study astronomy to write an ode titled "I cieli. A M.ss Mary Somerville" (Milano: Coi tipi del Dott. Francesco Vallardi, 1853).

${ }^{9}$ Gaetano Spandri, letter to Giambattista Pianciani, June 28, 1840, Historical Archives of the Pontifical Gregorian University (Archivio Storico della Pontificia Università Gregoriana, Roma) (hereafter APUG), MS Fund 574 (Correspondence Pianciani-Spandri), fol. 653v.

${ }^{10}$ Antonio Pighi, "Primo cinquantenario dalla morte di Gaetano Spandri astronomo veronese. Cenno biografico," Verona Fedele 38, no. 223 (Verona: Scuola Tipografica Nigrizia, 1909), 7.

${ }^{11}$ These piles, which he partly sold to private customers, schools, and universities, were able to reach high potential difference (from a hundred volts to a thousand or so). Still, they generated currents of very low intensity, about $\mu \mathrm{A}$. The final result was that these piles could stay charged and functioning for a very long time, even several years. 
${ }^{12}$ For further information, see Roberto Mantovani and Fiamma Negrini, "Zamboni e i suoi strumenti: le origini della collezione storica del Liceo Ginnasio Scipione Maffei di Verona," in Proceedings of the 30th Annual Congress of the Italian Society of the Historians of Physics and Astronomy, ed. Roberto Mantovani, 317-34 (Urbino: Argalia editore, 2012).

${ }^{13}$ Sometimes also "Giacomo."

${ }^{14}$ Alessandro Carli, "Storia dell'Accademia d'Agricoltura Commercio ed Arti di Verona dall'anno 1801 fino al 1809 e letta in Pubblico nell'Adunanza del 27 Aprile 1810," Memorie dell'Accademia d'Agricoltura, Commercio ed Arti di Verona, vol. 5 (Verona: Tipografia Mainardi, 1815), 439-41. See also, Antonio Camerlengo, letter to the Academy of Verona, October 5, 1806, Academy of Agriculture, Science and Letters, Verona (Accademia di Agricoltura, Scienze e Lettere di Verona) (hereafter AASLVr), MS Envelope 1805-10, XIII.3, fol. 1r.

${ }^{15}$ Giuseppe Zamboni, Domenico Barbieri, Antonio Provolo, and Giovanni Scopoli, "Della macchina a vapore del signor Bartolommeo Avesani ingegnere meccanico. Rapporto estratto degli Atti Accademici, sessione del giorno 7 agosto 1830," Memorie dell'Accademia d'Agricoltura Commercio ed Arti di Verona, vol. 13 (Verona: tipografia Libanti, 1831), 3-15. See also Giovanni Scopoli, "Rapporto della Commissione incaricata dell'esame della Macchina a Vapore inventata e costruita dall'Ingegnere Meccanico Sig. Bartolomeo Avesani," AASLVr, MS 1830.09.88, fols. 3r$7 \mathrm{r}$ and $8 \mathrm{r}-13 \mathrm{v}$.

${ }^{16}$ Antonio Rivato, Per le solenni esequie dell'Abate Giuseppe Zamboni prof. di Fisica e Matematica Applicata fatte nella cattedrale il giorno 11 dicembre 1846. Elogio dell'Abate Antonio Rivato Prof. di Filosofia dell'I. R. Liceo Convitto e socio di varie Accademie (Verona: Tipografia Libanti, 1847), 19.

${ }^{17}$ Pighi, "Primo cinquantenario" (ref. 10), 5.

${ }^{18}$ Giuseppe Zamboni, letter to Gaetano Spandri, undated, Civic Library, Verona (Biblioteca Civica, Verona) (hereafter CLVr), MS Autografoteca Scolari, Envelope 273.

${ }^{19}$ This instrument aroused the curiosity of Luigi Pacinotti (1807-89), director of the cabinet of physics of Pisa University. In a December 18, 1834, letter, the Pisan physicist Ranieri Gerbi (17631839) asked Zamboni to send the new instrument to Pacinotti.

${ }^{20}$ Rivato, Per le solenni esequie (ref. 16), 19.

${ }^{21}$ Gaetano Spandri, letter to Giambattista Pianciani, undated, ca. 1854-55, APUG, MS, Fund 574 (Correspondence Pianciani-Spandri), fol. 664r: for a description of the apparatus, see Francesco Frezzolini, "Descrizione dell'apparato elettromagnetico a scosse graduate dei sig. Kemp e Comp." L'album Giornale Letterario e di Belle Arti 12 (May 3, 1845), 74-76.

${ }^{22}$ Giovanni Federico Majer, "Il pendolo elettromagnetico del professor Dal Negro descritto da G. Federico Majer," Poligrafo. Giornale di Scienze Lettere ed Arti e Commentario delle conversazioni scientifico-letterarie che si riuniscono mensilmente nella casa del Direttore Nob. Cavaliere Giovanni Orti 2, May-June (Verona: Tipogr. Poligrafica di G. Antonelli, 1836), 98-99.

${ }^{23}$ Gaetano Spandri, letter to Giambattista Pianciani, March 13, 1847, APUG, MS Fund 574 (Correspondence Pianciani-Spandri), fol. 660r.

${ }^{24}$ Spandri, letter to Pianciani, March 13, 1847 (ref. 23), fol. 660v.

${ }^{25}$ Cesare Leopoldo Gazzaniga, letter to Francesco Zantedeschi, December 26, 1844, CLVr, MS Fund Zantedeschi, Envelope 886, fol. 16.3/4.

${ }^{26}$ Giovanni Antonio De Campostrini, "Storia degli anni MDCCCXXXVI, XXXVII, XXXVIII," Memorie dell'Accademia d'Agricoltura, Commercio ed Arti di Verona, vol. 16 (Verona: Tipografia Libanti, 1840), 131.

${ }^{27}$ Spandri, letter to Pianciani, March 13, 1847 (ref. 23). 
28 "10 marzo 1847, Istromento. Rogito 2338 del Notaio Giuseppe Donatelli di Verona," State Archives, Verona (Archivio di Stato, Verona) (hereafter SAVr), MS; a manuscript copy of this notary dead is also available at the Jesuit Archive of Gallarate (Varese).

${ }^{29}$ Gaetano Spandri, letter to Giambattista Pianciani, August 20, 1856, APUG, MS Fund 574 (Correspondence Pianciani-Spandri), fol. 666r.

${ }^{30}$ Francesco Vecchiato, "Castelnuovo del Garda e il 1848 veronese nella cronaca inedita di Gaetano Spandri," in Il martirio di Castelnuovo: 11 aprile 1848," Atti del Convegno nel 160 anniversario della strage: 11 aprile 2008, ed. Gondola V. S. (Verona: Accademia di Agricoltura Scienze e Lettere di Verona, 2009), 29.

${ }^{31}$ This inventory was published in 2015 in a dissertation I supervised. The thesis was written and presented at the University of Urbino in the Academic Year 2010-11 by Fiamma Negrini, a diligent scholar who has now sadly passed away. The publication, edited by Chiara Contri, is: Fiamma Negrini, La Scienza a Verona nella prima metà dell'Ottocento (Montagnana: Tipografia moderna, September 30, 2015).

${ }^{32}$ Giuseppe Zamboni, Sull'elettromotore perpetuo. Istruzione teorico-pratica (Verona: Tip. di Giuseppe Antonelli, 1843), 91.

${ }^{33}$ Gaetano Spandri, letter to Giambattista Pianciani, August 24, 1856, APUG, MS Fund 574 (Correspondence Pianciani-Spandri), fol. 668r.

${ }^{34}$ Cesare Leopoldo Gazzaniga, "Circa lo sviluppo di calore e di luce anche a temperature molto basse nel contatto del fosforo coll'iodio. Con annotazione finale di A. Fusinieri," Annali delle Scienze del Regno Lombardo-Veneto 3 (1833), 225-28.

${ }^{35}$ Gaetano Spandri, "Elenco delle memorie pubblicate dal Dottor Cesare Leopoldo Gazzaniga di Pavia professore di fisica e storia naturale nell'Istituto Filosofico di Desenzano: accompagnata ciascuna memoria da un breve sunto," August 8, 1839, AASLVr, MS 1839.08.283, fols. 1r-8r; in particular see the synthesis of memoir no. 4, titled "Sull'infiammazione del fosforo a contatto del iodio".

${ }^{36}$ For details see Negrini, "La Scienza a Verona" (ref. 31), 140.

${ }^{37}$ This model proposed by Saxton was known in Italy as "Newman's machine," after its maker, John Newman, 122 Regent Street, London, who commercialized it.

${ }^{38}$ The machine was brought from London to Rome by colonel Michele dei Duchi Caetani, commander of the metropolitan police of Rome. He sold it to Pianciani for the cabinet of physics of the Roman College.

${ }^{39}$ A discussion of these experiments can be found in Roberto Mantovani, "Un fisico dimenticato: il gesuita G. B. Pianciani," in Proceedings of the 22th Annual Congress of the Italian Society of the Historians of Physics and Astronomy (Genova-Chiavari, June 6-8, 2002), ed. Matteo Leone, Alessandro Paoletti and Nadia Robotti, 295-313 (Recco: Stampa Microart's 2004).

${ }^{40}$ Angelo Secchi, Intorno alla vita e alle opere del P. Giambattista Pianciani D. C. D. G. già professore nel Collegio Romano e Presidente del Collegio Filosofico dell'Università Romana Ec. Ec. Discorso del P. Angelo Secchi D. C. D. G. letto all'Accademia Tiberina il dì 19 maggio 1862 seguito da un elenco degli scritti del medesimo P. Pianciani e da un inno del Sig. Avv. Paolo Tarnassi (Roma: Tipografia delle Scienze Matematiche e Fisiche, 1862), 31.

${ }^{41}$ Giambattista Pianciani, "Saggio sui fenomeni d'induzione magnetoelettrica, letto all'Accademia de' Lincei il giorno 8 agosto 1836," Giornale Arcadico di Scienze Lettere ed Arti 69 (1836), $257-86$.

${ }^{42}$ We refer to the Historical Archives of the Pontifical Gregorian University (APUG), Fund 574 (Correspondence Spandri-Pianciani). It collects seventeen letters sent by Spandri to Pianciani. The correspondence developed from September 1837 to August 24, 1856. This correspondence has 
recently been published: Roberto Mantovani and Giovanni Maria Briganti, "La corrispondenza scientifica tra il veronese Gaetano Spandri e il gesuita Giambattista Pianciani," Rendiconti dell'Accademia Nazionale delle Scienze detta dei XL. Memorie di Scienze Fisiche e Naturali, ser. 5, vol. 41, pt. 2, tome 1 (Roma: Accademia Nazionale delle Scienze detta dei XL, 2018), 205-37.

${ }^{43}$ Gaetano Spandri, letter to Giambattista Pianciani, September 28, 1837, APUG, MS Fund 574 (Correspondence Pianciani-Spandri), fols. 651r-651v.

${ }^{44}$ Secchi gives us this information. The Lusverghs (sometimes also spelt Luswerghs) were a prolific and distinguished dynasty of instrument makers who worked in Rome from the second half of the seventeenth century to the end of the nineteenth century.

${ }^{45}$ Gaetano Spandri, letter to Giambattista Pianciani, May 12, 1838, APUG, MS Fund 574 (Correspondence Pianciani-Spandri), fols. 652r-652v.

${ }^{46}$ It consisted of putting current across thin platinum wires, prepared according to the method developed in 1813 by the English chemist and physicist William Wollaston (1766-1828). This use caused the immediate ignition of the wire. Two years later, in a letter dated June 28, 1840, Spandri sent Pianciani a small apparatus he had made "for the ignition of platinum" as a sign of gratitude. See Spandri, letter to Pianciani, June 28, 1840 (ref. 9), fol. 653r.

${ }^{47}$ Giuseppe Zamboni, Jacopo Bertoncelli, and Giulio Sandri, letter to Academy of Agriculture, July 10, 1838, AASLVr, MS Archive 1838-40, fol. 146r.

${ }^{48}$ Spandri, letter to Pianciani, June 28, 1840 (ref. 9), fols. 653r-653v.

${ }^{49}$ Spandri, letter to Pianciani, June 28, 1840 (ref. 9), fol. 653r.

${ }^{50}$ The change concerned the mercury switch reversing the induced currents. He substituted the two metal points that alternately immersed in mercury with a metal wheel, when rotating. This change produced the desired effects only for electrolysis experiments.

${ }^{51}$ Saxton's machine had a bundle of magnetized bars mounted horizontally. In 1836 a second magneto-electric machine came to market, devised by Irish instrument-maker Edward Marmaduke Clarke (1791-1859), with magnets mounted vertically. Spandri, drawing inspiration from both, added eight vertical magnetized bars to the bundle of ten horizontal magnets (for a complete description of the machine in the 1847 inventory, see ref. 36).

52 Gaetano Spandri, "La macchina magneto-elettrica di Newman. Memoria letta il 4 agosto 1842," AASLVr, MS B. II. 29, fols. 1r-5v.

${ }^{53}$ Spandri, "La macchina magneto-elettrica" (ref. 52), fols. 5r-5v.

${ }^{54}$ Alberto Meschiari, "Il libro de' conti del laboratorio di Giovanni Battista Amici," Atti della Fondazione Giorgio Ronchi 56, no. 1 (Firenze: Tip. L'Arcobaleno, January-February 2001), 79.

${ }^{55}$ Gaetano Spandri, letter to Giovanni Battista Amici, January 19, 1843, Archive of Estense University Library, Modena (Archivio della Biblioteca Estense Universitaria, Modena) (hereafter AEULMd), MS Envelope XIV, file n. 1004, fol. 7239r; for a description of this microscope, see: Giovanni Battista Amici "Description du petit microscope achromatique de M. Amici," Annales de Chimie et de Physique 12, Troisième Série (1844), 117-20.

${ }^{56}$ Giovanni Antonio De Campostrini, "Sulle uova dei bachi da seta. Memoria presentata all'Accademia d'Agricoltura, Commercio ed Arti di Verona il dì $1^{\circ}$ settembre 1842, letta nella tornata 5 gennaio 1843 dal Presidente G. Antonio De Campostrini, Scudiere di S. M. I. R. A. ecc.," Giornale Agrario Lombardo-Veneto e continuazione degli Annali di Agricoltura, vol. 19 (Milano: Società degli Editori degli Annali Universali delle Scienze e dell'Industria, May 1843), 273.

${ }^{57}$ In the Lombard-Venetian region, a thousand francs were about 1,150 Austrian lire.

${ }^{58}$ Carlo Dell'Acqua, Catalogo di Apparati per le Scienze d'Osservazione ed Esperienza che si fabbricano nell'Officina del Meccanico Carlo dell'Acqua assistente-preparatore alla Scuola di Fisica 
e Meccanica presso l'I. R. Liceo di S. Alessandro in Milano (Milano: Tipografia di Vincenzo Guglielmini, 1847), 14.

${ }^{59}$ Giovanni Battista Amici, letter to Gaetano Spandri, January 26, 1843, AEULMd, MS Envelope XIV, file n. 1004, fol. 7241r.

${ }^{60}$ Spandri, letter to Amici, January 19, 1843 (ref. 55), fol. 7239r.

${ }^{61}$ The file reports precious information on the mechanical structure of the instrument, on its accessories, on its maintenance, and the use of lenses. These were thirteen achromatic lenses mounted on circular shallow brass boxes fastened to each other in various ways and arranged to form seven different series to produce different enlargements.

${ }^{62}$ Alberto Meschiari, "Schede tecniche e istruzioni per l'uso di 160 microscopi di Giovanni Battista Amici. Parte terza: 1830-46” Atti della Fondazione Giorgio Ronchi 57, no. 2 (Firenze: Tip. L'Arcobaleno, March-April 2002), 312-17.

${ }^{63}$ Gaetano Spandri, letter to Giovanni Battista Amici, October 1, 1843, AEULMd, MS Envelope XIV, file n. 1004, fol. 7252r.

${ }^{64}$ Gaetano Spandri, letter to Giovanni Battista Amici, June 11, 1851, AEULMd, MS Envelope XIV, file n. 1004, fol. 7258r.

${ }^{65}$ The memoir Spandri received was: Giovanni Battista Amici, "Microscopical Observations on Grape Disease," Continuazione degli Atti della R. Accademia economico-agraria dei Georgofili di Firenze 30 (1852), 405-6.

${ }^{66}$ See "Elenco dei membri componenti l'Accademia d'Agricoltura, Commercio ed Arti di Verona" Memorie dell'Accademia d'Agricoltura, Commercio ed Arti di Verona, vol. 21 (Verona: Tipografia Libanti, 1841), 322.

${ }^{67}$ For the reports list, see ref. 82.

${ }^{68}$ Academy of Agriculture, letter to Gaetano Spandri, November 24, 1845, AASLVr, MS Archive 1844-46, 1845.11.518.

${ }^{69}$ Giuseppe Beretta, "Relazione storica de' fatti dell'Accademia veronese degli anni MDCCCXXXIX, XL, LI," Memorie dell'Accademia d'Agricoltura, Commercio ed Arti di Verona, vol. 20 (Verona: Tipografia Libanti, 1842), 136.

${ }^{70}$ Gaetano Spandri, "Analisi delle acque della bassa provincia veronese. Presentato il 10 dicembre 1840. Letto nella seduta del 25 febbraio 1841," MS. This manuscript wasn't found in the AASLVr.

${ }^{71}$ Maggi's asked: what was the thermal conductivity ratio for a magnetized body and a nonmagnetized one? To answer this question, with Spandri's help, he devised the following experiment: he took a soft iron disc and covered it with a thin wax layer. Then he heated its center and saw that the heat spread isotropically in wider and wider circles. Then he did the same, but with the disc under the influence of a magnetic current. This showed an asymmetric spreading of the heat because, instead of a disc, the melting wax sketched an ellipse with the smaller diameter "in the direction of the poles" and the larger in the direction "of the magnetic equator." Antonio Manganotti, "Storia della Accademia di Agricoltura Commercio ed Arti di Verona per il triennio 1848-49-50," Memorie dell'Accademia d'Agricoltura, Commercio ed Arti di Verona, vol. 29 (Verona: Tip. Antonelli, 1853), 19.

${ }^{72}$ Spandri, "Elenco delle memorie pubblicate" (ref. 35).

${ }^{73}$ Gazzaniga had worked for a short period, at the University of Pavia meteorological observatory. See Cesare Leopoldo Gazzaniga, "Saggio di un metodo per registrare le osservazioni meteorologiche al fine di dedurne con maggiore probabilità i corrispondenti pronostici," Giornale di Fisica, Chimica, Storia Naturale Medicina ed Arti de' professori P. Configliachi e G. Brugnatelli 9, decade 2 (1826), 146-51, 218-34. In 1849 Gazzaniga presented the following note at the Verona 
Academy: "Nota sopra un modo semplice di compilare e trar profitto dalle osservazioni meteorologiche"; see Antonio Manganotti, "Storia della Accademia di Agricoltura" (ref. 71), 57.

${ }^{74}$ Giuseppe Zamboni, report to Academy of Agriculture, December 17, 1838, attachment A: "Piano di Osservazioni Meteorologiche da eseguirsi nel nuovo Gabinetto dell'Orto BotanicoAgrario dell'Accademia d'Agricoltura, Arti e Commercio di Verona," AASLVr, MS Archive 1838-40, 1838.12.164, fols. 1r-2v.

${ }^{75}$ Giacomo Bertoncelli, "Osservazioni meteorologiche per l'anno 1841 scritte dal Sozio [sic] Giacomo Bertoncelli d'ordine dell'Accademia d'Agricoltura Arti e Commercio in Verona," Memorie dell'Accademia d'Agricoltura Commercio ed Arti di Verona, vol. 20 (Verona: Tipografia Libanti, 1842), 157-73.

${ }^{76}$ Gaetano Spandri, letter to Academy of Agriculture, March 11, 1845, AASLVr, MS Archivio 1844-46, 1845.03.320.

${ }^{77}$ Gaetano Spandri, "Osservazioni meteorologiche per l'anno 1848 fatte per commissione dell'Accademia di Agricoltura Arti e Commercio in Verona dal Socio Gaetano Spandri letta nella tornata 24 maggio 1849," Memorie dell'Accademia d'Agricoltura Commercio ed Arti di Verona, vol. 23 (Verona: Tipografia Antonelli, 1849), 177-94. The handwritten register of these observations is kept in the Verona Civic Library. It contains Spandri's transcripts of the data he had received by the Academy, which had been collected by Bertoncelli in the first eight months of 1848; see Gaetano Spandri, "Osservazioni meteorologiche per l'Anno 1848 fatte per Commissione dell'Accademia dal Socio G. Spandri,” CLVr, MS 2230.

${ }^{78}$ This thermometer was of the maximum-minimum type: during the day, it could register the maximum and minimum temperatures without the constant presence of an observer.

${ }^{79}$ Gaetano Spandri, "Osservazioni meteorologiche per l'anno 1848” (ref. 77), 180.

${ }^{80}$ This historical building was located near the General Post Office in central Verona.

${ }^{81}$ Spandri's six annual reports, written between 1848 and 1853, are published in the Academy's Memoirs.

${ }^{82}$ The four Spandri's reports are as follows: "Cenni intorno lo Scritto del Canonico Angelo Bellani sulle macchie delle foglie del gelso dette il seccume. Memoria letta il 4 settembre 1842," AASLVr, MS B. II. 21, fols. 2r-6r; "Rapporto della Memoria sui bachi e sui gelsi del canonico Angelo Bellani. Memoria letta il $1^{\circ}$ dicembre 1842," AASLVr, MS B. II. 27, fols. 1r-7v; "Rapporto della Memoria sui bachi da seta e sui gelsi del chiarissimo Abate Angelo Bellani Canonico. Memoria letta il 13 febbraio 1844," AASLVr, MS B. II. 28, fols. 1r-5r; "Alcune parole sul Discorso letto all'I.R. Istituto Lombardo dal Membro Effettivo Mons. Angelo Bellani, 'Sopra quanto ancor rimarrebbe a sapersi intorno la coltivazione dei bachi da seta e dei gelsi.' Memoria letta il 2 maggio 1844," AASLVr, MS B. II. 26, fols. 1r-3v.

${ }^{83}$ Gaetano Spandri, "Cenni sulla memoria del dr. Cesare Leopoldo Gazzaniga professore di fisica e storia naturale nell'Istituto filosofico privilegiato di Desenzano. Tratta della reciproca influenza dell'un occhio coll'altro nel veder chiaro e distinto. Memoria letta il 9 febbraio 1843," AASLVr, MS B. II. 25, fols. 1r-4v. Gazzaniga had already published this study in several yearly chapters in the Annals of the Sciences of the Lombard-Venetian Kingdom. See Cesare Leopoldo Gazzaniga, "Della reciproca influenza dell'un occhio con l'altro nel veder chiaro e distinto. Esperimenti del Dott. Cesare Leopoldo Gazzaniga," in Annali delle Scienze del Regno Lombardo-Veneto for the years $1839,1840,1841,1842$, vols. 9-12.

${ }^{84}$ Gaetano Spandri, "Il magnetismo terrestre. Memoria nella quale si dà il sunto di una nota sullo stesso argomento del Prof. Cesare Leopoldo Gazzaniga. Memoria presentata il 6 marzo 1846 e letta il 25 febbraio 1847," AASLVr, MS B. II. 24, fols. 1r-9r. Gazzaniga had already published this study in the Annals of the Sciences of the Lombard-Venetian Kingdom: Cesare Leopoldo 
Gazzaniga, "Sopra il Magnetismo Terrestre, nota del Dott. Cesare Leopoldo Gazzaniga," Annali delle Scienze del Regno Lombardo-Veneto 12 (1842), 207-14, 245-57.

${ }^{85}$ Gaetano Spandri, Paolo Vignola, and Bartolomeo Bertoncelli, "Rapporto sulla luce elettrica, del Signor Luigi Rossi. Letto il 23 febbraio 1854," AASLVr, MS B. IV. 13, fols. 1r-2v.

${ }^{86}$ Gaetano Spandri and Jacopo Bertoncelli, "Sopra la Galvanoplastica. Memoria letta nella seduta del 12 maggio 1842," AASLVr, MS B. III. 21, fols. 2r-8r.

${ }^{87}$ Spandri and Bertoncelli, "Sopra la Galvanoplastica" (ref. 86), fol. 7r. See also Pietro Degli Emilj, "Storia dell'Accademia d'Agricoltura, Arti e Commercio di Verona degli anni MDCCCXLII, XLIII, XLIV letta nella pubblica adunanza del 28 Agosto 1845," Memorie dell'Accademia d'Agricoltura Commercio ed Arti di Verona, vol. 21 (Verona: Tipografia Libanti, 1846), 45-46.

${ }^{88}$ Gaetano Spandri and Jacopo Bertoncelli, letter to Academy of Agriculture, August 5, 1842, AASLVr, MS Archivio 1841-43.

${ }^{89}$ Gaetano Spandri, "Sulla nuova macchina di Callan. Memoria letta il 7 agosto 1845," AASLVr, MS B. II. 23, fols. 1r-7r.

${ }^{90}$ Pietro Degli Emilj, "Storia dell'Accademia d'Agricoltura" (ref. 87), 61; See also the Verona newspaper "Foglio di Verona," no. 106, September 3, 1845, 424.

${ }^{91}$ On the story of this machine and Spandri's involvement, see Roberto Mantovani, "An Original Mid-Nineteenth Century Scientific Instrument in Italy: Vincenzo Vignola's Induction Coil,” Advances in Historical Studies 4, no. 2 (2015), 85-96.

${ }^{92}$ An example of such methodology can be found in the then-passionate debate on the nature of electric current. The connection between the magneto-electric current and other "different kinds of electricity" was made via the identity of the observed phenomena. Consequently devices that produced electric current had to be "strengthened" to the utmost to classify physical, chemical, and physiological effects better and study their possible correlations.

Dipartimento di Scienze Pure e Applicate (DiSPeA),

Gabinetto di Fisica: Museo urbinate della Scienza e

della Tecnica, Università di Urbino Carlo Bo, Collegio Raffaello

Piazza della Repubblica 13

61029 Urbino, PU, Italy

e-mail: roberto.mantovani@uniurb.it 